\title{
Dynamic and Sex-Specific Changes in Gonadotropin-Releasing Hormone Neuron Activity and Excitability in a Mouse Model of Temporal Lobe Epilepsy
}

\author{
(1) Jiang Li, ${ }^{1}$ Jordyn A. Robare, ${ }^{2}$ Liying Gao, ${ }^{3}{ }^{-}$M. Amin Ghane, ${ }^{2}$ Jodi A. Flaws, ${ }^{3}$ () Mark E. Nelson, ${ }^{1,2,4}$ \\ and (1) Catherine A. Christian, ${ }^{1,2,4}$
}

\section{DOI:http://dx.doi.org/10.1523/ENEURO.0273-18.2018}

\begin{abstract}
${ }^{1}$ Neuroscience Program, University of Illinois at Urbana-Champaign, Urbana, IL 61801, ${ }^{2}$ Department of Molecular and Integrative Physiology, University of Illinois at Urbana-Champaign, Urbana, IL 61801, ${ }^{3}$ Department of Comparative Biosciences, University of Illinois at Urbana-Champaign, Urbana, IL 61801, and ${ }^{4}$ Beckman Institute for Advanced Science and Technology, University of Illinois at Urbana-Champaign, Urbana, IL 61801
\end{abstract}

\begin{abstract}
Reproductive endocrine disorders are prominent comorbidities of temporal lobe epilepsy (TLE) in both men and women. The neural mechanisms underlying these comorbidities remain unclear, but hypothalamic gonadotropinreleasing hormone $(\mathrm{GnRH})$ neurons may be involved. Here, we report the first direct demonstrations of aberrant $\mathrm{GnRH}$ neuron function in an animal model of epilepsy. Recordings of $\mathrm{GnRH}$ neuron firing and excitability were made in acute mouse brain slices prepared two months after intrahippocampal injection of kainate (KA) or control saline, a well-established TLE model in which most females develop comorbid estrous cycle disruption. GnRH neurons from control females showed elevated firing and excitability on estrus compared with diestrus. By contrast, cells from KA-injected females that developed prolonged, disrupted estrous cycles (KA-long) showed the reverse pattern. Firing rates of cells from KA-injected females that maintained regular cycles (KA-regular) were not different from controls on diestrus, but were reduced on estrus. In KA-injected males, only GnRH neurons in the medial septum displayed elevated firing. In contrast to the diestrus versus estrus and sex-specific changes in firing, GnRH neuron intrinsic excitability was elevated in all KA-injected groups, indicating a role for afferent synaptic and neuromodulatory inputs in shaping overall changes in firing activity. Furthermore, KA-injected females showed cycle-stage-specific changes in circulating sex steroids on diestrus and estrus that also differed between KA-long and KA-regular groups. Together, these findings reveal that the effects of epilepsy on the neural control of reproduction are dynamic across the estrous cycle, distinct in association with comorbid estrous cycle disruption severity, and sex-specific.
\end{abstract}

Key words: excitability; GnRH; hormone; patch clamp electrophysiology; temporal lobe epilepsy

\section{Significance Statement}

People with epilepsy are at higher risk of reproductive endocrine disorders compared with the general population, but the neural mechanisms linking epilepsy and these comorbidities are unknown. Here, we report changes in the function of gonadotropin-releasing hormone $(\mathrm{GnRH})$ neurons, which control fertility, in a mouse model of temporal lobe epilepsy (TLE). GnRH neurons from epileptic female mice showed changes in activity dependent on estrous cycle stage and associated with severity of cycle disruption. The impacts of epilepsy on $\mathrm{GnRH}$ neurons in males were less severe. These findings provide novel evidence for impacts of epilepsy on GnRH neuron function, and will thus be of clinical relevance in developing new strategies to ameliorate reproductive comorbidities and to treat the underlying seizures and epilepsy. 


\section{Introduction}

Reproductive endocrine disorders are prominent comorbidities of epilepsy (Herzog et al., 1986a,b; Bilo et al., 2001; Klein et al., 2001; Löfgren et al., 2007; Bauer and Cooper-Mahkorn, 2008). For example, $10-20 \%$ of women with epilepsy develop polycystic ovary syndrome, in comparison to $5 \%$ of women without epilepsy (Bauer et al., 2000; Herzog, 2008). Disrupted menstrual cycle intervals and amenorrhea are also commonly observed (Herzog et al., 2003; Herzog, 2008; Zhou et al., 2012). Furthermore, semen abnormalities are reported in up to $90 \%$ of men with epilepsy (Herzog, 2008), and $10-30 \%$ of men with focal epilepsy develop low serum testosterone (T) levels (Talbot et al., 2008). The neural mechanisms linking epilepsy to comorbid reproductive endocrine disorders are unknown.

Temporal lobe epilepsy (TLE) is the most common focal epilepsy in patients of reproductive age (Engel, 2001). Roughly $60 \%$ of women with TLE not taking antiepileptic drugs exhibit menstrual disorders, indicating that there is a strong association between TLE seizures and reproductive endocrine dysfunction (Herzog et al., 1986a). Furthermore, seizures are exacerbated at certain phases of the menstrual cycle in $\sim 40 \%$ of women with epilepsy, a pattern termed catamenial epilepsy (Laidlaw, 1956; Herzog et al., 2004). One major type of catamenial epilepsy is characterized by a prolonged period of elevated seizure susceptibility and seizure clustering associated with an inadequate luteal phase within irregular, anovulatory menstrual cycles (Herzog et al., 1997). Therefore, seizure control through the restoration of proper reproductive cyclicity could be a novel therapeutic approach for many women with epilepsy. Understanding the mechanisms underlying epilepsy-induced reproductive endocrine disorders is crucial for the development of new strategies for both reproductive cycle maintenance and seizure management.

Received July 9, 2018; accepted September 5, 2018; First published September 11, 2018.

The authors declare no competing financial interests.

Author Contributions: JL and CAC designed research; JL, JAR, LG, MAG, and JAF performed research; JL, MEN, and CAC analyzed data; JL and CAC wrote the paper.

This work was supported by National Institutes of Health/National Institute of Neurological Disorders and Stroke (NIH/NINDS) grants R01 NS105825 and R03 NS103029 (CAC), startup funds from the University of Illinois at UrbanaChampaign (CAC), and a Beckman Institute Graduate Fellowship (JL).

Acknowledgements: We thank Jae Seong Kim for assistance with stereotaxic injections; Lillian Scanlon, Vincent Abejuela, Jason Lamano, and Shivang Chaudhary for assistance with estrous cycle monitoring and seizure video screening; Rana Youssef for assistance with histology; Justin Rhodes for assistance with logistic regression analysis; and Daniel Llano for helpful editorial comments.

Correspondence should be addressed to Catherine A. Christian, Department of Molecular and Integrative Physiology, University of Illinois at UrbanaChampaign, Urbana, IL 61801. E-mail: cathchri@illinois.edu.

DOI:http://dx.doi.org/10.1523/ENEURO.0273-18.2018

Copyright @ $2018 \mathrm{Li}$ et al.

This is an open-access article distributed under the terms of the Creative Commons Attribution 4.0 International license, which permits unrestricted use, distribution and reproduction in any medium provided that the original work is properly attributed.
The hypothalamic gonadotropin-releasing hormone $(\mathrm{GnRH})$ neurons are the final neural output driving the activity of downstream elements of the hypothalamicpituitary-gonadal (HPG) axis (Herbison, 2006; Christian, 2017). Because of the difficulty in measuring GnRH directly, luteinizing hormone (LH) is often used as a readout of $\mathrm{GnRH}$ secretion; pituitary gonadotrophs secrete bolus pulses of $\mathrm{LH}$ in response to pulsatile $\mathrm{GnRH}$ stimulation. Altered LH pulse frequency has been reported in both men and women with epilepsy (Herzog et al., 1990; Drislane et al., 1994; Quigg et al., 2002), suggesting epilepsyinduced changes in $\mathrm{GnRH}$ release. To date, studies of the impacts of epilepsy on GnRH neurons have been limited to anatomic analysis of $\mathrm{GnRH}$ immunoreactivity in animal models, with conflicting results (Amado et al., 1993; Friedman et al., 2002; Fawley et al., 2012). Whether GnRH neuron function is impaired in epilepsy has not been tested directly. Furthermore, it is unknown whether the impacts of epilepsy on $\mathrm{GnRH}$ neurons vary with the female reproductive cycle, or are different between males and females.

Multiple rodent models of TLE display disrupted estrous cycles (Amado et al., 1987; Edwards et al., 1999; Scharfman et al., 2008), including the intrahippocampal kainate (KA) mouse model (Li et al., 2017). Here, we studied the impacts of epilepsy on GnRH neuron function in this model of TLE. We assessed the spontaneous firing rate and intrinsic excitability of $\mathrm{GnRH}$ neurons in brain slices obtained from females (on diestrus and estrus) and males approximately two months after intrahippocampal injection of KA or control saline. Diestrus and estrus were chosen for examination as these stages are associated with changes in seizure susceptibility in rodents (Finn and Gee, 1994; Maguire et al., 2005) and show the greatest degree of change in this model of TLE (Li et al., 2017). Periodic burst firing may underlie GnRH secretion (Kelly and Wagner, 2002). Therefore, we also analyzed the burst properties of the recorded GnRH neurons. Sex steroids exert potent feedback on GnRH neuron activity (Pielecka et al., 2006; Moenter et al., 2009), and altered serum sex steroid levels were reported in other rodent models of epilepsy (Amado et al., 1987; Amado and Cavalheiro, 1998; Edwards et al., 2000; Scharfman et al., 2008). Therefore, we measured serum progesterone $\left(P_{4}\right)$ and estradiol $\left(E_{2}\right)$ in control and KA-injected females, and T in males. Our results indicate that the effects of intrahippocampal KA injection on GnRH neuron activity and excitability are different on diestrus compared with estrus, varied according to the severity of comorbid estrous cycle disruption, and sex-specific.

\section{Materials and Methods}

\section{Animals}

All animal procedures were approved by the Institutional Animal Care and Use Committee of the University of Illinois at Urbana-Champaign. GnRH-tdTomato transgenic mice were bred by crossing $\mathrm{GnRH}-\mathrm{Cre}^{+}$females (Yoon et al., 2005; The Jackson Laboratory \#021207) and Ai9 males (Madisen et al., 2010; The Jackson Laboratory \#007909). Both strains are on the C57BL/6J background. 
Mice were housed in a standard environment in a 14/10 h light/dark cycle (7:00 P.M. lights off) to promote breeding and estrous cyclicity (Fox et al., 2006), with up to five mice per cage. Genotyping to identify pups expressing the Cre allele was done by PCR of DNA extracted from tail clips collected before postnatal day $(P) 21$ using the following four primer sequences as suggested by The Jackson Laboratory: (1) transgene reverse CGG ACA GAA GCA TTT TCC AG; (2) transgene forward ACA GGT GTC TGT CCC ATG TCT; (3) internal positive control forward CAA ATG TTG CTT GTC TGG TG; (4) internal positive control reverse GTC AGT CGA GTG CAC AGT TT.

\section{Estrous cycle monitoring}

A regular mouse estrous cycle is typically $4-5 \mathrm{~d}$ long (Byers et al., 2012). Because mouse estrous cycles can be disrupted easily by environmental or other stressors, we categorized cycles up to $6 \mathrm{~d}$ in length as "regular" to account for minor temporal disruption and to minimize false positives of estrous cycle disruption. To confirm that all female mice had regular estrous cycles, daily vaginal smears were performed between 10:00 A.M. and 12:00 P.M. starting on or after P42. A total of $20 \mu \mathrm{l}$ of sterile PBS was gently inserted into the vaginal cavity using a 100- to $200-\mu l$ sterile pipette tip, quickly withdrawn, and examined on a microscope slide by brightfield microscopy. Regular estrous cycles were defined as at least two cycles 4-6 d in length with proestrus, estrus, metestrus, and diestrus $1 /$ II stages occurring in chronological order. Smears were classified into each stage based on the following criteria: (1) proestrus: dominated by nucleated epithelial cells; (2) estrus: dominated by cornified epithelial cells; (3) metestrus: both cornified epithelial cells and leukocytes; (4) diestrus I: dominated by leukocytes; (5) diestrus II: few or no cells present. Mice that did not display regular estrous cycles within three weeks of monitoring were excluded from further study.

After intrahippocampal injection of either saline or KA, mice were allowed to rest undisturbed for one month to minimize stress and avoid disruption of epileptogenesis. Daily estrous cycle monitoring was then performed until the time of brain slice preparation. The vaginal smears from KA-injected females did not show major changes in smear cytology characteristics. Therefore, the same criteria were used to classify estrous cycle stages for all mice. To promote cyclicity both before and after saline/KA injection, soiled bedding from cages housing male mice was introduced to cages housing females when irregular cyclicity was noted. The average cycle length used to categorize KA-injected mice as "KA-long" (i.e., estrous cycle period $\geq 7 \mathrm{~d}$ ) or "KA-regular" was calculated from the daily monitoring for the time from $42 \mathrm{~d}$ after injection to the day of brain slice preparation. Cycle period was chosen as the primary parameter for characterization because elongation of the estrous cycle is a prominent feature of cycle disruption in this model of TLE (Li et al., 2017).

\section{Intrahippocampal injections}

Stereotaxic injections in mice eight weeks of age and older were performed under 2-3\% oxygen-vaporized iso- flurane anesthesia (Clipper Distributing Company). KA (Tocris Bioscience; $50 \mathrm{nl}$ of $20 \mathrm{mM}$ prepared in $0.9 \%$ sterile saline) was injected into the right dorsal hippocampal CA1 region (coordinates: $1.8 \mathrm{~mm}$ posterior and 1.5 $\mathrm{mm}$ lateral to bregma; $1.5 \mathrm{~mm}$ ventral to the cortical surface). Control mice were injected with an equivalent volume of sterile saline. Carprofen ( $5 \mathrm{mg} / \mathrm{kg}$, Zoetis) was administered subcutaneously at the beginning of surgery for analgesia. After closing the scalp incision with sutures, anesthetic $2.5 \%$ lidocaine $+2.5 \%$ prilocaine cream $(\mathrm{Hi}-$ Tech Pharmacal) and Neosporin antibiotic gel (Johnson and Johnson) were applied to the wound.

\section{Video monitoring of acute seizures}

After intrahippocampal injection surgery was completed, mice were placed in a transparent and warmed recovery chamber. All KA-injected mice were video monitored to screen for the development of acute seizures within $5 \mathrm{~h}$ after unilateral KA injection. Behavioral seizures of Racine stage 3 (forelimb clonus) and higher (rearing and falling) could be distinguished through the video, whereas behavioral seizures below stage 3 (slight head nodding and facial muscle contraction) could not. Freezing or continuous back-circling behaviors indicating nonconvulsive status epilepticus, as previously reported in this model (Bouilleret et al., 1999; Riban et al., 2002), were also noted.

\section{Brain slice preparation}

Acute brain slices were prepared approximately two months after saline/KA injection. All mice were euthanized by decapitation between 10:00 and 11:00 A.M.; 300- $\mu \mathrm{m}$ coronal brain sections were prepared using a Leica VT1200S (Leica Biosystems) vibrating blade microtome. Brain slices were bathed in oxygenated $\left(95 \% \mathrm{O}_{2}, 5 \%\right.$ $\mathrm{CO}_{2}$ ) ice-cold sucrose solution (containing $2.5 \mathrm{mM} \mathrm{KCl}$, $1.25 \mathrm{mM} \mathrm{NaH}_{2} \mathrm{PO}_{4}, 10 \mathrm{mM} \mathrm{MgSO}, 0.5 \mathrm{mM} \mathrm{CaCl}_{2}, 11 \mathrm{mM}$ glucose, and $234 \mathrm{mM}$ sucrose) during sectioning and then transferred to oxygenated artificial CSF (ACSF) for $30 \mathrm{~min}$ at $32^{\circ} \mathrm{C}$ before being transferred to room temperature for at least $30 \mathrm{~min}$. ACSF contained $2.5 \mathrm{mM} \mathrm{KCl}, 10 \mathrm{mM}$ glucose, $126 \mathrm{mM} \mathrm{NaCl}, 1.25 \mathrm{mM} \mathrm{NaH}{ }_{2} \mathrm{PO}_{4}, 1 \mathrm{mM}$ $\mathrm{MgSO}_{4}, 0.5 \mathrm{mM} \mathrm{CaCl}_{2}$, and $26 \mathrm{mM} \mathrm{NaHCO}_{3}$; osmolarity $\sim 298$ mOsm. For recording, individual slices were placed in a recording chamber on the stage of an upright $\mathrm{BX} 51 \mathrm{WI}$ microscope (Olympus America). Oxygenated bath ACSF was warmed to $30-32^{\circ} \mathrm{C}$ using an inline heater (Warner Instruments) and pumped through the slice chamber at a flow rate of $2.5 \mathrm{ml} / \mathrm{min}$.

\section{Targeted extracellular recordings}

Targeted extracellular (loose patch) recordings (Nunemaker et al., 2002; Christian et al., 2005) were performed between 11:00 A.M. and 3:00 P.M. for 40-90 min/cell to detect spontaneous firing activity. Thick-walled borosilicate glass recording pipettes ( $\sim 2 \mathrm{M} \Omega$ tip resistance) were prepared using a P-1000 electrode puller (Sutter Instruments) and filled with filtered ACSF solution with $10 \mathrm{mM}$ HEPES buffer added. GnRH neurons expressing tdTomato red fluorescence were identified by brief illumination at $593 \mathrm{~nm}$ and targeted for recording under differential 
infrared contrast optics using an sCMOS camera (OrcaFlash 4.OLT, Hamamatsu Photonics). Seal resistance was measured at least every $30 \mathrm{~min}$. The initial seal resistances ranged from 3.2 to $12 \mathrm{M} \Omega$ and the maximum seal resistance was $45 \mathrm{M} \Omega$. Recordings were performed in voltage-clamp mode with the holding potential at $0 \mathrm{mV}$ and Bessel-filtered at $12 \mathrm{kHz}$. No more than three cells were recorded per animal. If a cell displayed no action currents within $1 \mathrm{~h}$ of recording, $15 \mathrm{mM} \mathrm{KCl}$ was bathapplied to induce firing and confirm successful recording. A picture of the pipette tip position was captured using HClmage software (Hamamatsu) after every recording for neuron location analysis. Classification of soma position in the medial septum (MS), preoptic area (POA), or anterior hypothalamic area (AHA) was based on a mouse brain atlas (Paxinos and Franklin, 2012; corresponding plates: $\mathrm{MS}=23-25, \mathrm{POA}=25-28, \mathrm{AHA}=29$ ). Data acquisition was performed with a MultiClamp 700B amplifier, Digidata 1550 digitizer, and Clampex 10 software (Molecular Devices). Action current detection was performed using Clampfit 10.6.

\section{Current-clamp recordings}

Recordings were performed in the presence of ionotropic GABA and glutamate receptor blockers added to the bath solution (5 $\mu \mathrm{M}$ APV $+20 \mu \mathrm{M}$ DNQX $+100 \mu \mathrm{M}$ picrotoxin, Abcam). Recording pipettes (3-5 M $\Omega$ ) were filled with a pipette internal solution containing $125 \mathrm{mM}$ K-gluconate, $20 \mathrm{mM} \mathrm{KCl,} 10 \mathrm{mM}$ HEPES, 4 mM EGTA, 4 $\mathrm{mM}$ Mg-ATP, $0.4 \mathrm{mM} \mathrm{Na-GTP}$, and $0.1 \mathrm{mM} \mathrm{CaCl}$; $\mathrm{pH}$ 7.2 , osmolarity $290 \mathrm{mOsm}$. After achieving the whole-cell configuration using conventional procedures, a 5-mV depolarizing step from $-70 \mathrm{mV}$ holding potential was delivered in voltage-clamp mode to measure series and input resistances. Only recordings with series resistance $<20$ $\mathrm{M} \Omega$ and input resistance $>500 \mathrm{M} \Omega$ were included in analyses. Resting membrane potential was maintained near -73 mV (calculated after correction for a 13-mV liquid junction potential) by applying injected current as needed. All recordings were made in bridge-balanced mode. Data acquisition was performed as for targeted extracellular recordings. Data analysis was performed in Clampfit 10.6 for all parameters except action potential (AP) threshold, which was determined in MATLAB (MathWorks) from the value on the phase plot where the $d \mathrm{~V} / \mathrm{dt}$ was $\geq 5 \mathrm{~V} / \mathrm{s}$. The area under the frequency-current (F-I) curve for each neuron was calculated by a trapezoidal method.

\section{Firing pattern categorization and burst analysis}

Spike train and burst detection analyses were performed in MATLAB. Firing patterns from targeted extracellular recordings were analyzed by constructing an interspike interval (ISI) joint scatter plot, which used the log ISI before ( $x$-axis, logISIn) and after $(y$-axis, logISIn + 1) a spike to reveal the temporal relationship of neural spikes (Ramcharan et al., 2000; Dodla and Wilson, 2010). For group comparisons of burst properties, 100 bursts were randomly selected from each neuron to construct cumulative probability distributions. For recordings with fewer than 100 bursts, all detected bursts were used.
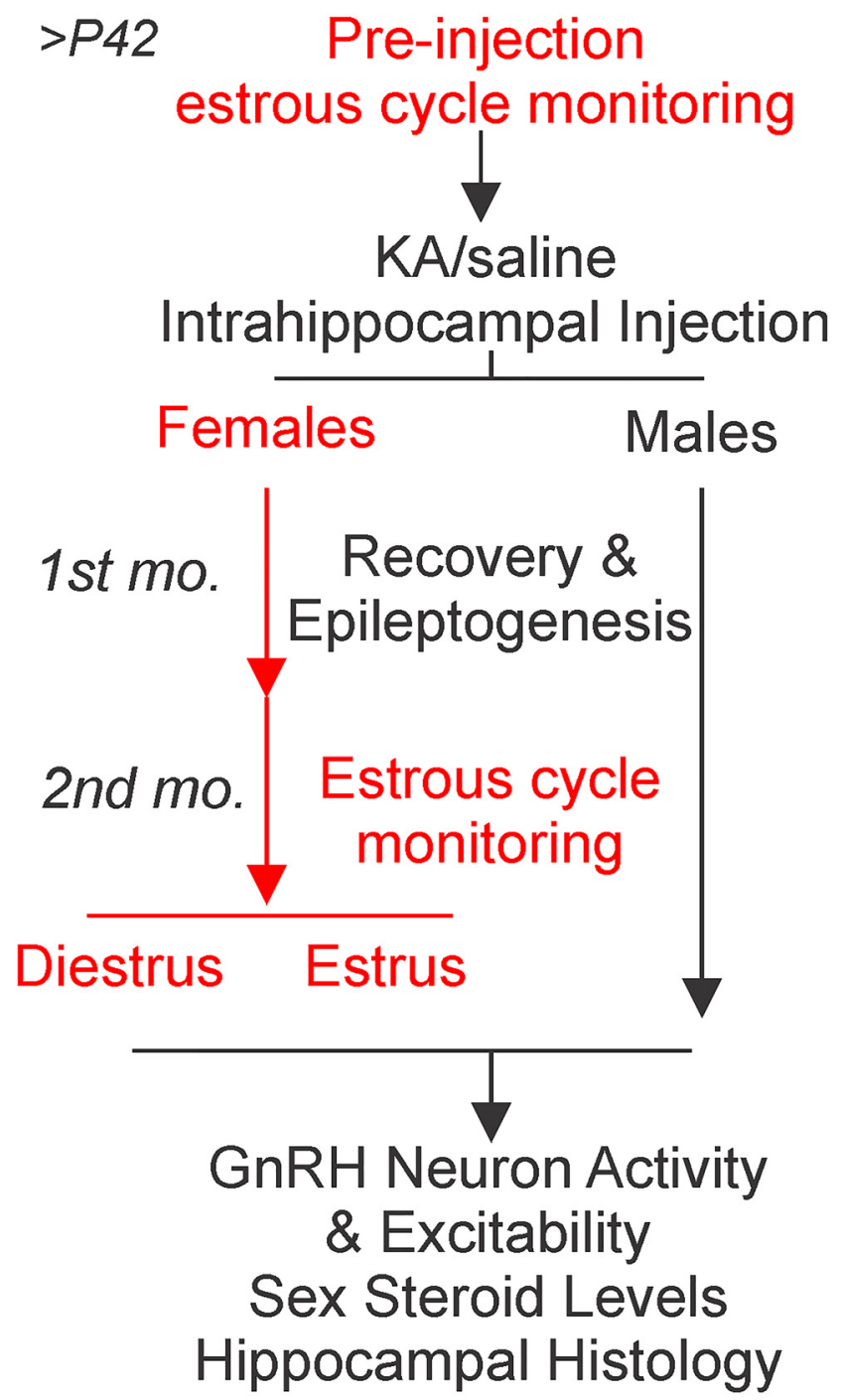

Figure 1. Experimental design and timeline illustrating paradigm of test groups, procedures, and experimental time points. Procedures exclusive to experiments in females are marked in red.

\section{Code accessibility}

The code used for $\mathrm{GnRH}$ neuron firing pattern recognition, burst detection, burst properties analysis, and statistical comparisons of burst activities is available on Github (https://github.com/ChristianLabUIUC/BurstAnalysis). All code is also available as Extended Data Figure 1.

\section{Cresyl violet and glial fibrillary acidic protein (GFAP) staining of hippocampus}

At the conclusion of brain slice preparation, the remaining portion of cerebrum containing the hippocampus was collected, fixed in $4 \%$ PFA for $24 \mathrm{~h}$ at $4^{\circ} \mathrm{C}$, and preserved in $30 \%$ sucrose solution with $0.5 \%$ sodium azide at $4^{\circ} \mathrm{C}$ until sectioning; $50-\mu \mathrm{m}$ coronal hippocampal sections were prepared using a freezing microtome (SM 2010R, Leica Biosystems). Four to eight sections per mouse from the dorsal hippocampal region were used for verification of hippocampal sclerosis by cresyl violet staining and 
gliosis by GFAP staining. For cresyl violet staining, sections were mounted on charged glass slides, stained with cresyl violet (Sigma C5042) for $12 \mathrm{~min}$ at room temperature $\left(\sim 22^{\circ} \mathrm{C}\right)$, dehydrated with graded ethanol solutions (70-100\%), and cleaned in xylene. For GFAP immunostaining, floating sections were incubated in an anti-GFAP mouse monoclonal antibody (1:1000, Sigma G3893) for $48 \mathrm{~h}$ at $4^{\circ} \mathrm{C}$ on a shaker, followed by incubation in Fluorescein horse anti-mouse secondary antibody (1:1000, Vector Laboratories $\mathrm{Fl}-2000$ ) for $2 \mathrm{~h}$ at room temperature on a shaker. Sections were then mounted on charged glass slides and coverslipped using Vectashield Hardset Antifade Mounting Medium with DAPI (Vector Laboratories $\mathrm{H}-1500)$. Image acquisition was performed using a BX43 light and fluorescence microscope (Olympus) equipped with a Q-Color 3 camera and QCapture 6 software (QImaging).

\section{Hormone assays}

Trunk blood samples from mice used for in vitro recordings ( $n=85$ mice) were collected at the time of brain slice preparation. Samples from mice not used for recordings ( $n=12$ mice) were collected after decapitation to replace samples from recorded mice that were contaminated or otherwise unsuitable for analysis. The blood samples were kept at room temperature $\left(\sim 22^{\circ} \mathrm{C}\right)$ for $20 \mathrm{~min}$ and then on ice for $20 \mathrm{~min}$, followed by centrifugation at room temperature for $15 \mathrm{~min}$. Serum was withdrawn after centrifugation and stored at $-20^{\circ} \mathrm{C}$ until use. ELISAs $\left(\mathrm{P}_{4}\right.$ : DRG Diagnostics; $\mathrm{E}_{2}$ : Calbiotech; T: IBL America) were performed according to the manufacturers' instructions. Some samples were diluted to match the volume required for the testing. Samples were run in duplicate and the average of the duplicate was used as the final hormone concentration value for each mouse.

\section{Experimental design and statistics}

The experimental design is outlined in Figure 1. Preinjection estrous cycle monitoring for adult female mice started on or after P42. Age-matched female and male mice were stereotaxically injected with saline or KA in the dorsal hippocampus. Two months after injection, acute brain slices were prepared and $\mathrm{GnRH}$ neuron firing rate and excitability were measured via single-cell electrophysiological recordings. For female mice, recordings were performed on the days of diestrus or estrus. At the time of brain slice preparation, trunk blood serum and hippocampal tissue were collected for hormone analysis and histology, respectively.

Statistical comparisons were made using OriginPro (OriginLab), SPSS (IBM), or R software. Comparisons between two groups (e.g., diestrus vs estrus within each treatment group, and saline vs KA for males) were made using $t$ tests or Mann-Whitney tests depending on the normality of the data, which was determined using Shapiro-Wilk tests. Comparisons between saline, KA-long, and KA-regular females were made separately for diestrus and estrus using Kruskal-Wallis and Dunn's post hoc tests or one-way ANOVA and Bonferroni post hoc tests based on the normality and the homogeneity of variance within each group as assessed by Shapiro-Wilk tests and
Levene's tests, respectively. Data for evoked firing rate and excitability parameters were Box-Cox transformed to achieve normal distributions, and analyzed using threeway ANOVA and Fisher's LSD post hoc tests. Comparisons of $P_{4}$ and $E_{2}$ levels between saline, KA-long, and KA-regular groups at each cycle stage were made using one-way ANOVA and Fisher's post hoc tests; nonnormally distributed data were normalized by logtransformation before analysis. Results in the above tests are reported as means \pm SEM. Firing patterns of GnRH neurons from female mice were assessed using a logistic regression with treatment group (saline, KA-long, and $\mathrm{KA}$-regular) and estrous cycle stage (diestrus and estrus) as factors. The probabilities of neurons displaying bursting, irregular, tonic, or quiet firing patterns were analyzed separately using Fisher's exact tests. Comparisons were made between treatment groups within diestrus or estrus, or within treatment groups between diestrus and estrus. $\chi^{2}$ tests were used to compare the proportions of $\mathrm{GnRH}$ neurons from control and $\mathrm{KA}$-injected male mice that showed bursting and irregular firing patterns, and to compare the proportions of KA-long and KA-regular mice showing hippocampal sclerosis. Correlation analysis was performed using Spearman's rank-order tests. Statistical significance in the above statistical tests was set at $p<$ 0.05 . Cumulative probability distributions were compared using Kolmogorov-Smirnov goodness-of-fit tests, and the criterion for statistical significance in these tests was $p<$ 0.001 .

\section{Results}

\section{Confirmation of hippocampal KA injection targeting}

Mice treated with intrahippocampal KA exhibit acute non-convulsive or mild clonic status epilepticus followed (within two weeks to two months) by spontaneous focal seizures that rarely generalize to tonic-clonic seizures, along with histopathological features including hippocampal sclerosis and gliosis, recapitulating cardinal hallmarks of human TLE (Bouilleret et al., 1999; Riban et al., 2002; Blümcke et al., 2013). In these studies, we applied three steps of verification to check the accuracy of intrahippocampal injections: (1) video screening of seizures immediately after KA injection; (2) histopathological assessment of hippocampal sclerosis by cresyl violet (Nissl) staining; and (3) immunofluorescent GFAP staining for gliosis. The small subset of mice that were used for trunk blood collection only, without in vitro recordings, all displayed acute seizures following KA injection. Therefore, hippocampal tissue used for histology was collected on the day of brain slice preparation for in vitro recordings (approximately two months after injection).

The large majority of KA-injected female mice (57 of 69 , $83 \%$ ) showed at least two seizures within $5 \mathrm{~h}$ after KA injection, and five mice showed one seizure. Of the remaining seven mice, three stayed frozen or exhibited backwards circling over the entire recording, one mouse did not show seizures or frozen/backwards circling behavior after KA injection, and three were not successfully video recorded (Table 1). Four of these seven mice displayed prominent granule cell dispersion and other signs 
Table 1. Outcomes of video screening of acute seizures and hippocampal histology to verify KA injection targeting

\begin{tabular}{|c|c|c|c|c|}
\hline \multicolumn{5}{|c|}{ Video screening outcome (acute seizures) } \\
\hline & $>2$ seizur & 1 seizu & No seizures or video & Total \\
\hline Females & 57 & 5 & 7 & 69 \\
\hline Males & 10 & 0 & 5 & 15 \\
\hline \multicolumn{5}{|c|}{$\begin{array}{l}\text { Histology for mice with no seizures or video (2 months post- } \\
\text { KA injection) }\end{array}$} \\
\hline & Sclerosis & Gliosis & No sclerosis or gliosis & Total \\
\hline Females & 4 & 2 & $1 *$ & 7 \\
\hline Males & 5 & 0 & 0 & 5 \\
\hline
\end{tabular}

Number of seizures refers to behavioral seizures (Racine stage 3 or higher) observed within $5 \mathrm{~h}$ of KA injection. Hippocampal tissue from mice that either did not show acute seizures or for whom videos were not available was collected approximately two months after KA injection. Sclerosis was assessed via cresyl violet (Nissl) staining. Sections of hippocampi that did not display signs of sclerosis were further assessed for gliosis via GFAP staining; *, mouse removed from dataset in absence of either video confirmation of acute seizure induction or later development of hippocampal sclerosis/gliosis.

of sclerosis in cresyl violet staining, as shown in the example in Figure $2 A$. Hippocampi that showed no obvious signs of sclerosis were subsequently evaluated for GFAP staining. In two of the remaining three mice examined, gliosis was observed in the dentate gyrus and/or CA regions in the injected hippocampus, as shown in the example in Figure $2 B$. The remaining KA-injected female, which did not show acute seizures, hippocampal sclerosis, nor gliosis, was excluded from the final dataset. No signs of sclerosis or gliosis were observed in the dentate gyrus or CA regions collected from randomly selected saline-injected mice (Fig. 2C). Neither gliosis nor hippocampal sclerosis were observed in the contralateral hippocampus.

Video screening of $13 \mathrm{KA}$-injected males confirmed that $10(77 \%)$ showed at least two seizures (Table 1). The remaining three mice did not show any behavioral seizures but were confirmed to have developed hippocampal sclerosis by two months after injection. Two other male mice were not successfully video recorded, but were confirmed by cresyl violet staining to have developed hippocampal sclerosis.

\section{Rate of development of hippocampal sclerosis does not correlate with severity of comorbid estrous cycle disruption}

A subset of $\mathrm{KA}$-injected females can maintain regular estrous cyclicity through two months after injection (Li et al., 2017). This resilience may reflect inaccuracy of the initial injection or reduced induction of hippocampal damage. Therefore, the hippocampi of all KA-injected females that maintained regular 4- to 6-d estrous cycles (KAregular) were examined by histology, even if acute seizures were detected in the videos. Hippocampi of 12 out of the 20 mice $(60 \%)$ in this group showed granule cell dispersion in cresyl violet staining (Fig. 2A). Seven of the remaining eight mice showed gliosis with GFAP staining (Fig. 2B). The remaining mouse was not confirmed by histology due to problems with tissue sectioning, but remained in the final dataset as it was confirmed to have shown acute seizures.
A

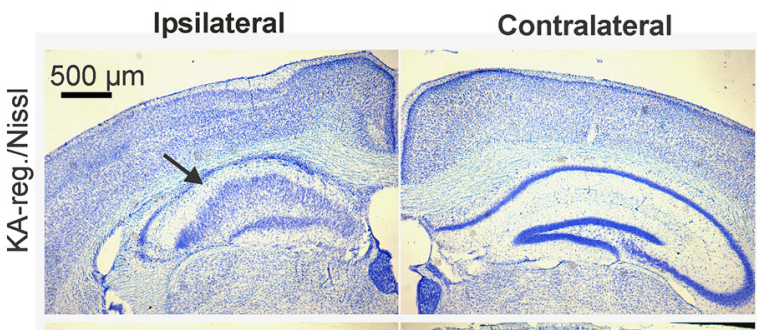

B
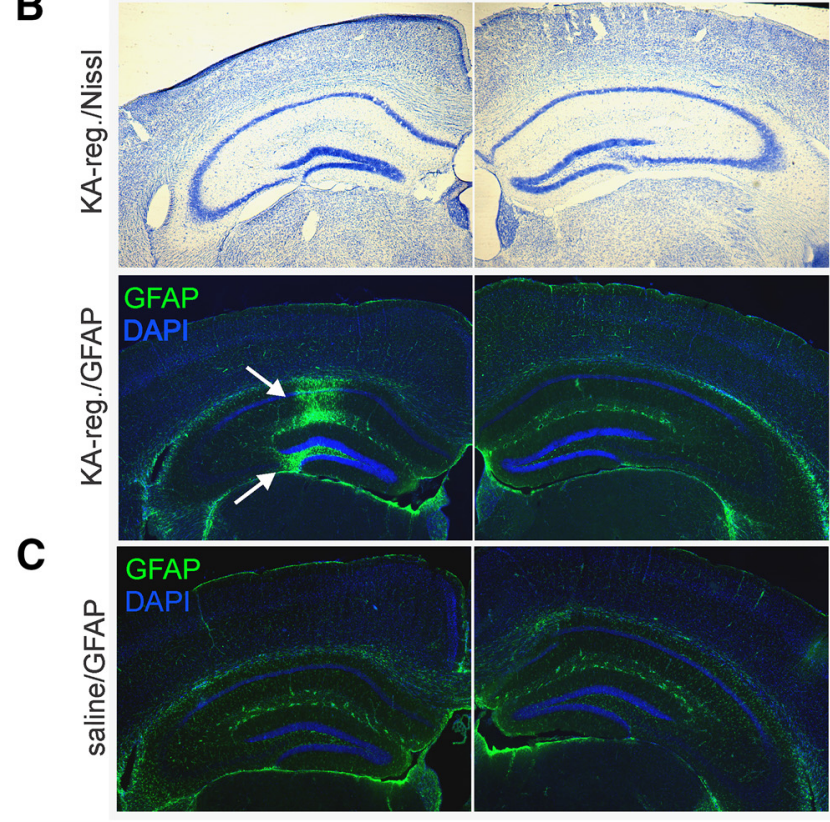

Figure 2. Verification of KA injection targeting. A, Example cresyl violet staining from a KA-regular female with marked granule cell dispersion ipsilateral to the injection, and intact hippocampus contralateral to the injection. $\boldsymbol{B}$, Cresyl violet (top) and GFAP/ DAPI staining (bottom) from a KA-regular female. Note the strong GFAP immunoreactivity in the injected hippocampus, despite absence of major pathology observed in cresyl violet staining of adjacent sections. GFAP, green; DAPI, blue. Left, Ipsilateral to the injection. $\boldsymbol{C}$, Example GFAP staining in tissue from a salineinjected mouse. Scale bar: $500 \mu \mathrm{m}$. Black arrow, hippocampal sclerosis detected by cresyl violet stain; white arrows, gliosis in $\mathrm{CA}$ and dentate gyrus detected by GFAP staining.

To determine whether the presentation of sclerosis was higher in mice that developed prolonged estrous cycle lengths ( $\geq 7 \mathrm{~d}$ period, KA-long), we evaluated the hippocampi of 25 randomly selected KA-long mice. Nineteen of these mice $(76 \%)$ showed sclerosis in cresyl violet staining; this proportion was not different from that of the KA-regular group $\left(p>0.6, \chi^{2}\right.$ test). These results indicate that the severity of comorbid estrous cycle disruption following KA injection is not directly correlated with the rate of induction of hippocampal sclerosis, and that downstream changes in the HPG axis likely play a significant role in driving the comorbidity.

\section{GnRH neurons from KA-injected female mice show altered firing rates on diestrus and estrus}

For studies of female mice, acute coronal brain slices were prepared on either diestrus or estrus approximately two months after intrahippocampal saline/KA injection. 
A

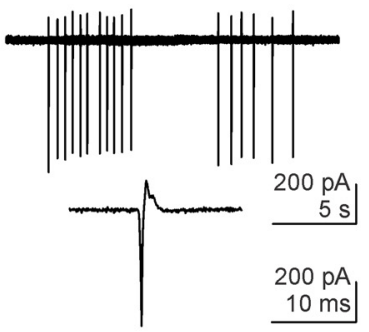

B

Saline Control Diestrus $(0.4 \mathrm{~Hz})$

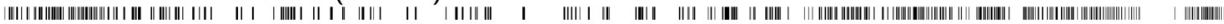

Saline Control Estrus $(0.6 \mathrm{~Hz})$

| II ||||| | | ||| || ||

KA Diestrus - High Firing Rate $(1.0 \mathrm{~Hz})$

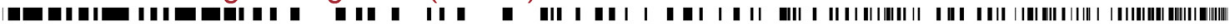
KA Diestrus - High Firing Rate $(3.8 \mathrm{~Hz})$

C

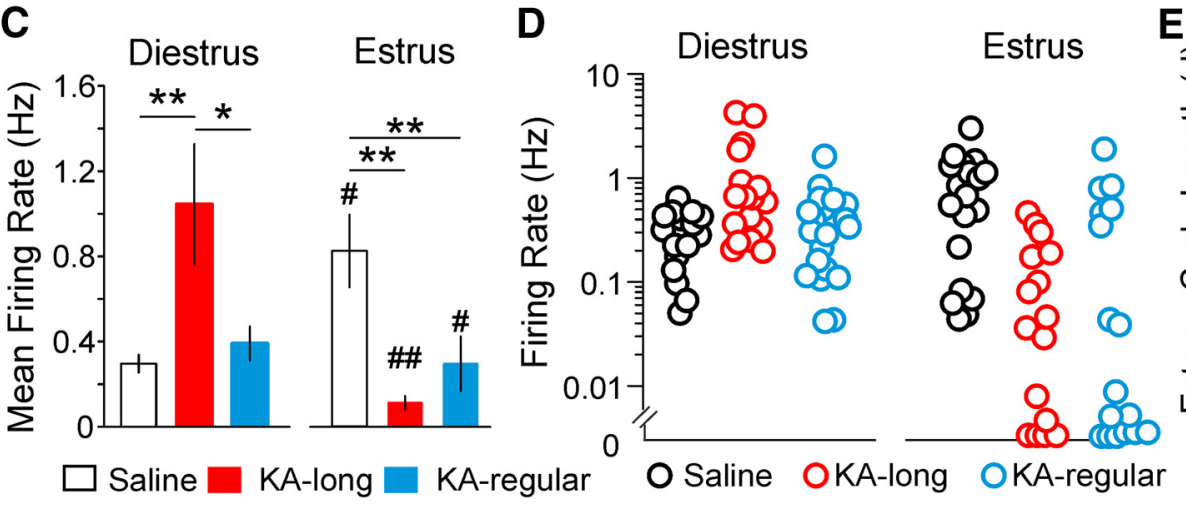

E $12 \quad$ Diestrus

KA Estrus - Low Firing Rate $(0.1 \mathrm{~Hz})$

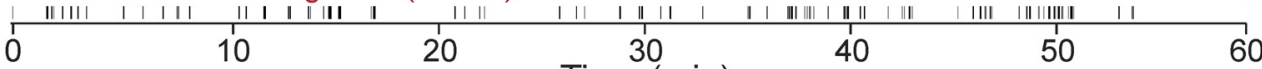

Time $(\mathrm{min})$

F
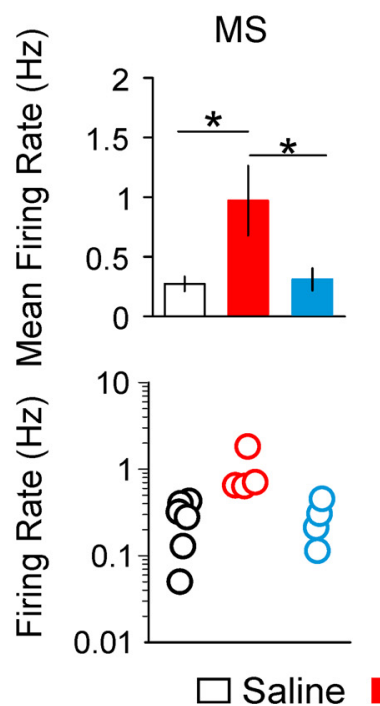

Diestrus POA
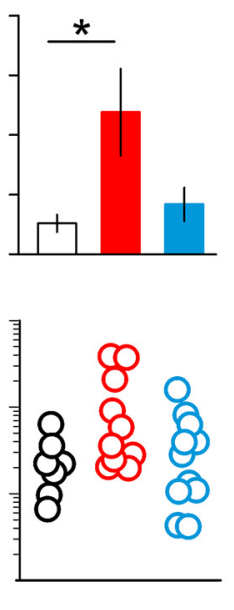

KA-long
G
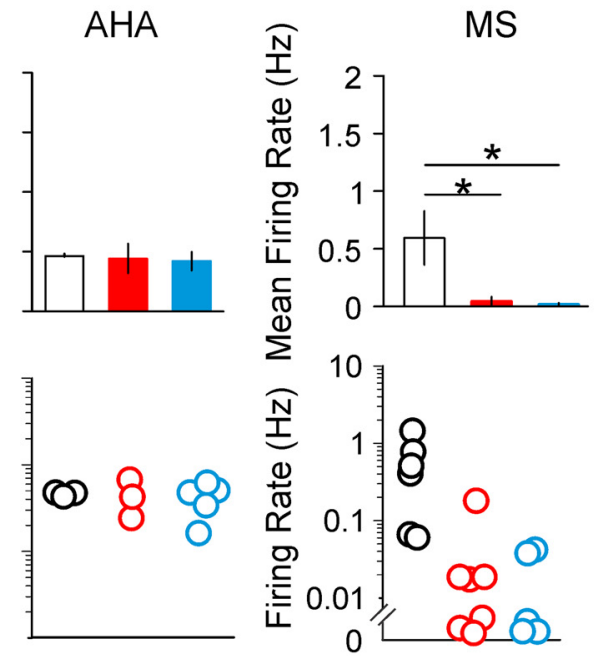

KA-regular

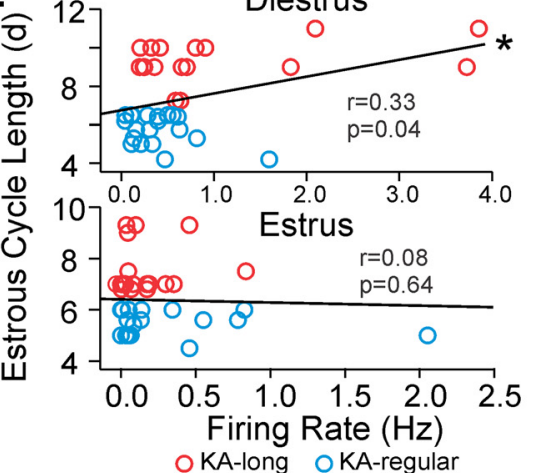

Estrus POA
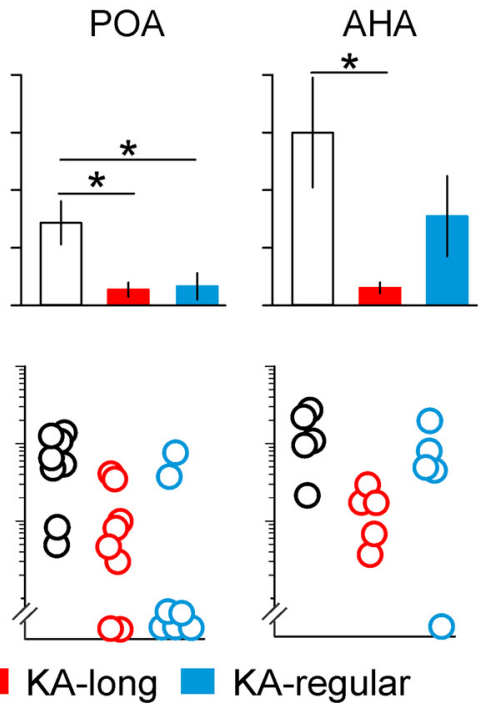

Figure 3. Diestrus versus estrus shifts in $\mathrm{GnRH}$ neuron mean firing rate are compromised in the intrahippocampal KA mouse model of TLE. A, Example raw traces of bursts (top) and individual (bottom) action currents detected in loose patch recordings. $\boldsymbol{B}$, Representative raster plots of activity in $\mathrm{GnRH}$ neurons from control and KA-injected females. The black arrow marks the end of recording. The mean firing rate of each cell is given in parentheses. $\boldsymbol{C}$, Mean $\pm \mathrm{SEM}$ for $\mathrm{GnRH}$ neuron firing rate in control (open bars), KA-long (red bars), and KA-regular (blue bars) groups. KA-injected females are divided into KA-long and KA-regular groups based on their estrous cycle length (KA-long $\geq 7 \mathrm{~d}, \mathrm{KA}$-regular 4-6 d). Cells were recorded on diestrus (left) or estrus (right). $\boldsymbol{D}$, Firing rates in individual cells, plotted on a logarithmic scale to show the full range. $\boldsymbol{E}$, Correlation analyses between $\mathrm{GnRH}$ neuron firing rate and estrous cycle length in KA-injected females performed with data combined from KA-long (red circles) and KA-regular (blue circles) groups. Black line, line of best fit for all points. $\boldsymbol{F}, \boldsymbol{G}$, Comparison of $\mathrm{GnRH}$ neuron firing rate between controls, KA-long, and KA-regular groups based on anatomic location of somata for cells recorded on diestrus (F) or estrus (G). Data are shown as group mean firing rates (top, mean \pm SEM) and individual neuron firing rates (bottom); $* p<0.05, * * p<0.01$ for comparisons between saline, KA-long, and KA-regular females by Kruskal-Wallis with Dunn's post hoc tests; \#p $<0.05$, \#\#p $<0.01$ for comparisons between diestrus and estrus within groups by $t$ tests or Mann-Whitney tests. In scatter plots of individual neuron firing rate, neurons plotted below $\mathrm{y}=0.01$ showed firing rates $\geq 0 \mathrm{~Hz}$ and below $0.01 \mathrm{~Hz}$. 
Targeted extracellular loose patch recordings were performed to detect spontaneous action currents, the fast currents underlying APs (Fig. $3 A$ ), in GnRH neurons. All $\mathrm{GnRH}$ neurons recorded were ipsilateral to the injected hippocampus. tdTomato ${ }^{+}$somata in the MS, POA, and AHA displaying the bipolar morphology typical of $\mathrm{GnRH}$ neurons were targeted for recording. GnRH neurons from control mice typically showed firing activity with periodic quiescence between groups (bursts) of action currents (Fig. 3B). Cells recorded on estrus had higher mean firing rates than cells recorded on diestrus (diestrus $n=16$ cells/8 mice, estrus $n=20$ cells/9 mice; $p=0.03$; MannWhitney test; Fig. $3 C, D$ ), providing novel evidence for an endogenous diestrus-to-estrus shift in mean firing rate in control conditions.

By contrast, $\mathrm{GnRH}$ neurons from KA-injected females showed abnormal firing patterns (Fig. 3B). On diestrus, $\mathrm{GnRH}$ neurons from KA-long mice ( $n=17$ cells/9 mice) showed an increase in mean firing rate compared with both control ( $n=16$ cells $/ 8$ mice, $p=0.01)$ and KAregular mice $(n=20$ cells/10 mice, $p=0.016$; KruskalWallis test/Dunn's). The mean firing rate of $\mathrm{GnRH}$ neurons from KA-regular females was not different from controls (Fig. $3 C$ ). GnRH neurons from KA-long females showed high firing rates $\leq 3.8 \mathrm{~Hz}$, although firing rates for some cells fell within the normal range (Fig. $3 D$ ). When the data from $\mathrm{KA}$-long and $\mathrm{KA}$-regular females were combined, there was a positive linear correlation between firing rate and cycle length on diestrus $(r=0.33, p=0.043$, Spearman's rank-order test; Fig. $3 E$ ). These results suggest that the impacts of KA injection on GnRH neuron firing activity on diestrus are correlated with the severity of comorbid estrous cycle disruption.

On estrus, GnRH neurons from both KA-long $(n=18$ cells/8 mice, $p=0.01)$ and KA-regular $(n=17$ cells $/ 7$ mice, $p=0.01$ ) females showed significantly lower firing rates compared with controls $(n=20$ cells/9 mice; Fig. $3 C$, Kruskal-Wallis test/Dunn's). Some cells from KA-long and KA-regular females showed only a few or no APs (Fig. $3 D$ ). GnRH neuron firing rate and estrous cycle length were not correlated on estrus $(r=0.082, p=0.64$, Spearman's test; Fig. $3 E$ ). Therefore, in contrast to the results obtained on diestrus, the impacts of KA injection on the firing activity of $\mathrm{GnRH}$ neurons on estrus are similar in mice with and without comorbid estrous cycle disruption. Moreover, the KA-induced impact on activity of $\mathrm{GnRH}$ neurons from KA-long mice is opposite that observed on diestrus.

Notably, in contrast to the typical elevation in firing on estrus compared with diestrus in control mice, the diestrus-to-estrus shift in firing was reversed in KA-long mice, with decreased firing on estrus compared with diestrus ( $p<0.0001$; Mann-Whitney test). Although mean firing rates of cells from KA-regular mice were similar between diestrus $(0.39 \pm 0.08 \mathrm{~Hz})$ and estrus $(0.29 \pm 0.13$ $\mathrm{Hz}$ ), a nonparametric Mann-Whitney test revealed a significant difference $(p=0.03)$, which appeared to be driven mainly by a subset of neurons with firing rates close to zero on estrus (Fig. 3D). These results suggest that KA injection disrupts the normal patterns of diestrus versus estrus changes in $\mathrm{GnRH}$ neuron firing activity.

\section{GnRH neuron location influences firing rate response to KA injection}

To determine whether the firing rate phenotype of each cell was influenced by the soma location, the recorded GnRH neurons were classified based on the location of the recording pipette tip in the MS, POA, or AHA. Although this analysis necessitated parsing the overall data into more groups, some of which only had a few cells, distinct patterns emerged based on the anatomic classification.

On diestrus, GnRH neurons in the MS from KA-long females ( $n=4$ cells $/ 4$ mice) showed higher firing rates than cells from controls $(n=6$ cells $/ 3$ mice, $p=0.034)$ and KA-regular mice $(n=4$ cells $/ 4$ mice, $p=0.043$, Kruskal-Wallis test/Dunn's). GnRH neurons in the POA from KA-long females ( $n=10$ cells $/ 7$ mice) had higher firing rates than neurons from controls $(n=7$ cells $/ 6$ mice, $p=0.025)$, and a borderline level of significance in comparison to neurons from KA-regular mice $(n=11 \mathrm{cells} / 9$ mice, $p=0.053$, Kruskal-Wallis test/Dunn's). Firing rates of cells in the AHA, however, were not different between the three groups (saline $n=3$ cells $/ 3$ mice, KA-long $n=3$ cells $/ 3$ mice, KA-regular $n=5$ cells $/ 5$ mice, $p>0.8$; Fig. $3 F$ ).

On estrus, $\mathrm{GnRH}$ neurons in the MS and POA from both KA-long $(n=5$ cells $/ 4$ mice MS, $n=8$ cells $/ 7$ mice POA) and KA-regular ( $n=5$ cells $/ 5$ mice MS, $n=7$ cells $/ 6$ mice $\mathrm{POA}$ ) females displayed decreased firing rates compared to controls $(n=6$ cells $/ 5$ mice MS, $n=8$ cells $/ 6$ mice POA; MS: KA-long vs saline $p=0.019$, KA-regular vs saline $p=0.042$; POA: KA-long vs saline $p=0.037$, KA-regular vs saline $p=0.045$, Kruskal-Wallis/Dunn's). Cells in the AHA from KA-long females recorded on estrus $(n=5$ cells $/ 5$ mice) showed decreased firing compared with controls ( $n=6$ cells $/ 5$ mice; KA-long vs saline $p=$ 0.027; Kruskal-Wallis test/Dunn's), but cells from KAregular mice ( $n=5$ cells/4 mice) were not different from controls (Fig. 3G). Together, these results indicate that, on both diestrus and estrus, firing rates of $\mathrm{GnRH}$ neurons in the MS and POA are most strongly affected following KA injection. On estrus, however, AHA cells also appear to be affected in mice with the most severe comorbid estrous cycle disruption.

\section{GnRH neuron firing patterns are altered following KA injection in female mice}

The full spike train of each recorded $\mathrm{GnRH}$ neuron was used to categorize firing patterns by constructing ISI joint scatter plots. The scatter plots were divided into four quadrants (clusters) by a series of candidate burst ISI threshold values. The optimal value among the candidate burst ISI thresholds was determined as the value at which the degree of proximity was highest for all four clusters, quantified as the intersection point of the cluster limit lines producing the lowest squared summed distance between all points within a cluster and its respective centroid (center of the cluster; Fig. $4 A$ ).

In accordance with other studies of $\mathrm{GnRH}$ neuron firing pattern in vitro and in vivo (Moenter et al., 2003; Constan- 

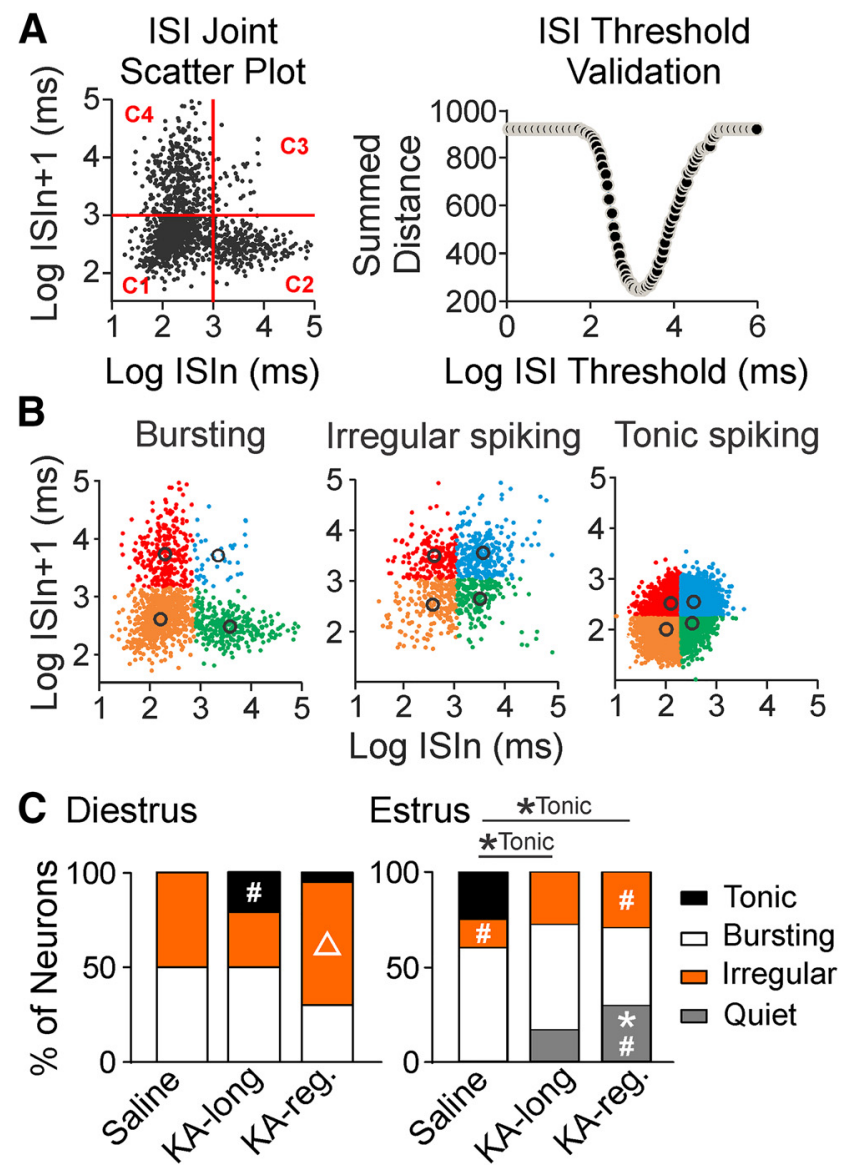

Figure 4. $\mathrm{GnRH}$ neuron firing patterns are altered in $\mathrm{KA}$-injected female mice on both diestrus and estrus. $\boldsymbol{A}, \boldsymbol{B}$, Examples of burst detection and firing pattern categorization. $\boldsymbol{A}$, left, Example ISI joint scatter plot with a randomly selected candidate burst ISI threshold value (red line). The four quadrants divide all data into four clusters: C1, C2, C3, and C4. Right, Example ISI threshold validation shows the summed distance for each candidate burst ISI threshold value. The summed distance is calculated by the summation of squared distance between every point and its corresponding cluster centroid. The candidate value with the smallest summed distance is chosen as the optimal burst ISI threshold. $\boldsymbol{B}$, Examples of scatter plots for $\mathrm{GnRH}$ neuron bursting (left), irregular spiking (middle), and tonic spiking (right) patterns. The different colors represent the final C1 to C4 distribution with the optimal burst ISI threshold for each cell. Black circles, individual centroids of clusters C1-C4. C, Proportion of $\mathrm{GnRH}$ neurons from female mice categorized into each pattern on diestrus (left) and estrus (right); $* p<0.05$ for pair-wise Fisher's exact test comparisons for indicated firing pattern between control and KA-injected groups; \#p $<0.05$ for comparisons for indicated firing pattern between diestrus and estrus within control and KA-injected groups. $\Delta, p<0.05$ for comparisons for indicated firing pattern between KA-long and KA-regular groups within the same estrous cycle stage.

tin et al., 2013), the neurons recorded in this dataset showed bursting, irregular spiking, or tonic spiking patterns (Fig. 4B). When a neuron shows a bursting pattern, each quadrant $(\mathrm{C} 1-\mathrm{C} 4)$ on the ISI scatter plot contains a cluster that encompasses the spikes within bursts, at the beginning of each burst, at the end of each burst, and outside the burst, respectively. In bursting neurons, the spikes in cluster C1 (lower left quadrant) outnumber other
Table 2. Effects of KA injection, estrous cycle stage, or an interaction between KA injection and cycle stage on probability of occurrence of each firing pattern in logistic regression analysis

\begin{tabular}{llll}
\hline & KA & Cycle & $\begin{array}{l}\text { Interaction of } \\
\text { KA injection } \\
\text { and cycle stage }\end{array}$ \\
Firing pattern & injection & stage & $0.0009 * * *$ \\
Tonic & 0.17 & 0.84 & 0.99 \\
Bursting & 0.18 & 0.30 & 0.25 \\
Irregular & 0.15 & $0.0072 * *$ & 1.00 \\
Quiet & $0.027 *$ & $0.0003 * * *$ & 1.00
\end{tabular}

$p$ values from logistic regressions performed for each firing pattern; $* p<$ $0.05, * * p<0.01, * * * p<0.001$.

clusters, producing a skewed distribution of ISI values across clusters. The number of spikes to define a burst was set more than or equal to four. Therefore, for a cell to be identified as a bursting neuron, the $\mathrm{C} 1$ cluster needed to contain at least two times as many points as $\mathrm{C} 2$ (lower right) and $\mathrm{C} 4$ (upper left), and at least five times as many points as C3 (upper right) in the ISI joint scatter plot. When a neuron showed an irregular or tonic spiking pattern, the ISI values were divided almost equally across the four quadrants. Neurons were classified as tonic spiking when the centroids for all clusters were located at ISI values $<1 \mathrm{~s}$.

The results of logistic regression analysis for each firing pattern examining effects of KA injection, cycle stage, and interaction between KA injection and cycle stage are summarized in Table 2. For burst firing, there were no effects of KA injection or cycle stage, and no interaction. For irregular spiking, there was an effect of cycle stage, but no effect of KA injection and no interaction. For tonic spiking, there were no effects of cycle stage or KA injection separately, but there was a significant interaction. For quiet cells, there were effects of both KA injection and cycle stage, but no interaction.

Group-specific differences for irregular, tonic, and quiet activity were further analyzed post hoc using pair-wise Fisher's exact tests (Fig. 4C). Cells from saline-treated controls showed a greater proportion of cells showing irregular spiking on diestrus compared with estrus $(p=$ 0.034). Analysis of tonic spiking showed a borderline significant difference between diestrus and estrus $(p=$ 0.053). Cells from KA-long mice showed more tonic firing on diestrus than on estrus ( $p=0.045$ ), and cells from KA-regular mice showed more irregular spiking on diestrus than on estrus $(p=0.049)$ and more quiescence on estrus than on diestrus $(p=0.014)$.

On diestrus, no differences were detected between KA-injected groups and controls for any firing pattern, but comparisons between the KA-long and KA-regular groups found that cells from KA-regular mice showed increased irregular spiking $(p=0.049)$, with no differences detected for tonic firing or quiescence. On estrus, cells from control mice showed more tonic firing in comparison to both KA-long $(p=0.048)$ and KA-regular $(p=0.049)$ groups. Cells from KA-regular mice also showed increased quiescence compared with controls $(p=0.014)$. No differences were detected between KA-long and KA-regular groups on estrus. On diestrus, the tonic-spiking neurons from 


\section{A Saline}

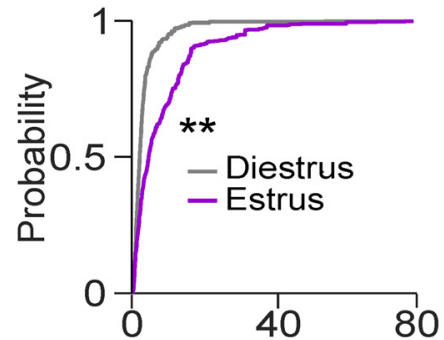

B Burst Duration (s)

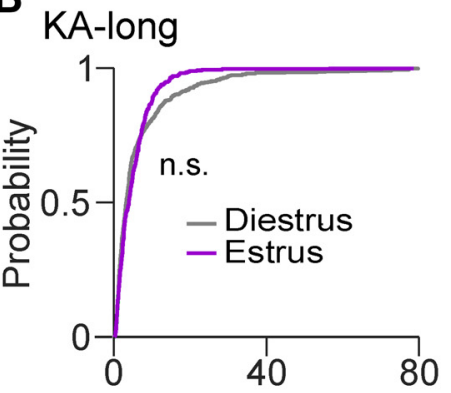

Burst Duration (s)

C KA-regular

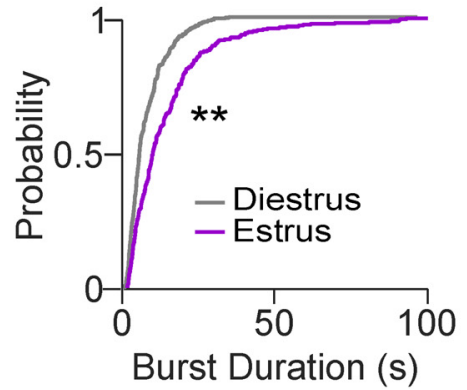

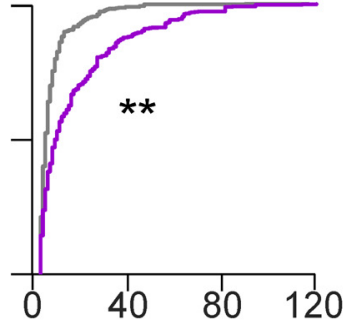

\# of Spikes/Burst

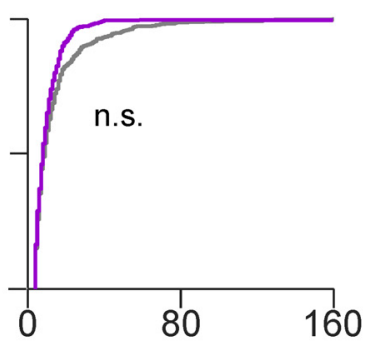

\# of Spikes/Burst

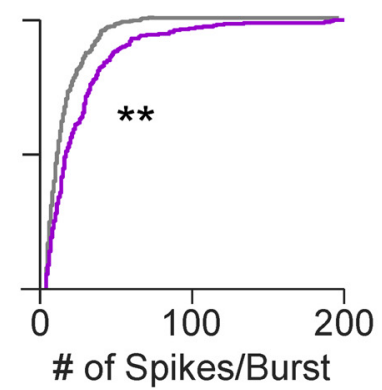

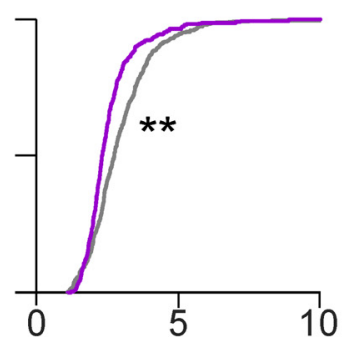

Intraburst Firing Rate $(\mathrm{Hz})$

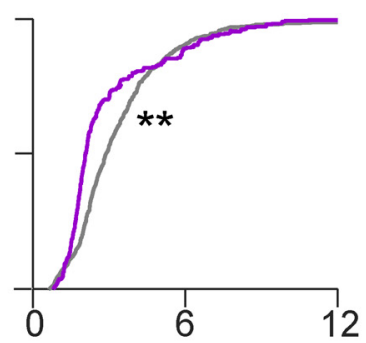

Intraburst Firing Rate $(\mathrm{Hz})$
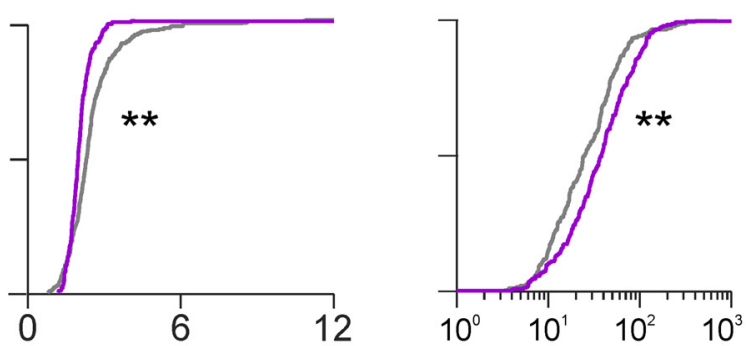

Intraburst Firing Rate $(\mathrm{Hz})$ Interburst Intervals (s)

Figure 5. GnRH neuron burst properties on diestrus and estrus; only neurons displaying burst spiking patterns were used for comparisons. A, Cumulative probability distributions for burst properties of $\mathrm{GnRH}$ neurons from control female mice on diestrus (gray traces) and estrus (purple traces). Cumulative distributions were constructed using 100 randomly selected bursts per cell. $\boldsymbol{B}$, Burst properties from KA-long female mice. C, Burst properties from KA-regular female mice; $* * p<0.0001$ for comparisons by Kolmogorov-Smirnov tests. n.s., not significant. The interburst intervals are presented on logarithmic scales for better visualization of the major portion (1-99\%) of the distributions.

$\mathrm{KA}$-long females were in the POA (three neurons) and MS (one neuron), and the one tonic-spiking neuron from a $\mathrm{KA}$-regular female was in the POA. On estrus, the tonicspiking neurons from controls were in the AHA (three neurons), POA (one neuron), and MS (one neuron), and quiet cells from both $\mathrm{KA}$-long and $\mathrm{KA}$-regular females were in the POA and MS (KA-long: two POA, one MS; $\mathrm{KA}$-regular three POA, two MS). Bursting and irregularspiking cells in all groups were evenly distributed across the MS, POA, and AHA. These results indicate that following $\mathrm{KA}$ injection, a subset of $\mathrm{GnRH}$ neurons in the MS and POA displays a continuous tonic firing activity pattern on diestrus that is not observed in controls. Furthermore, in stark contrast to the firing patterns observed on diestrus, subsets of $\mathrm{GnRH}$ neurons in the MS and POA show aberrant quiescence on estrus after KA injection.

\section{GnRH neuron burst properties are altered following KA injection in female mice}

To assess whether GnRH neuron burst firing (which may be linked to hormone release) is altered after KA injection, the cells that were categorized as "bursting" were further examined for detailed analysis of burst properties. Note that because bursting cells were distributed across all three anatomic areas examined, location categories were collapsed for this analysis.

GnRH neurons from control mice showed distinct burst properties between diestrus and estrus. Bursting cells showed longer burst duration, more spikes per burst, and slower intraburst firing rate on estrus compared with diestrus (diestrus $n=8$ cells, estrus $n=12$ cells; all $p<$ 0.0001 , pairwise Kolmogorov-Smirnov tests). The intervals between bursts were also longer on estrus than on 

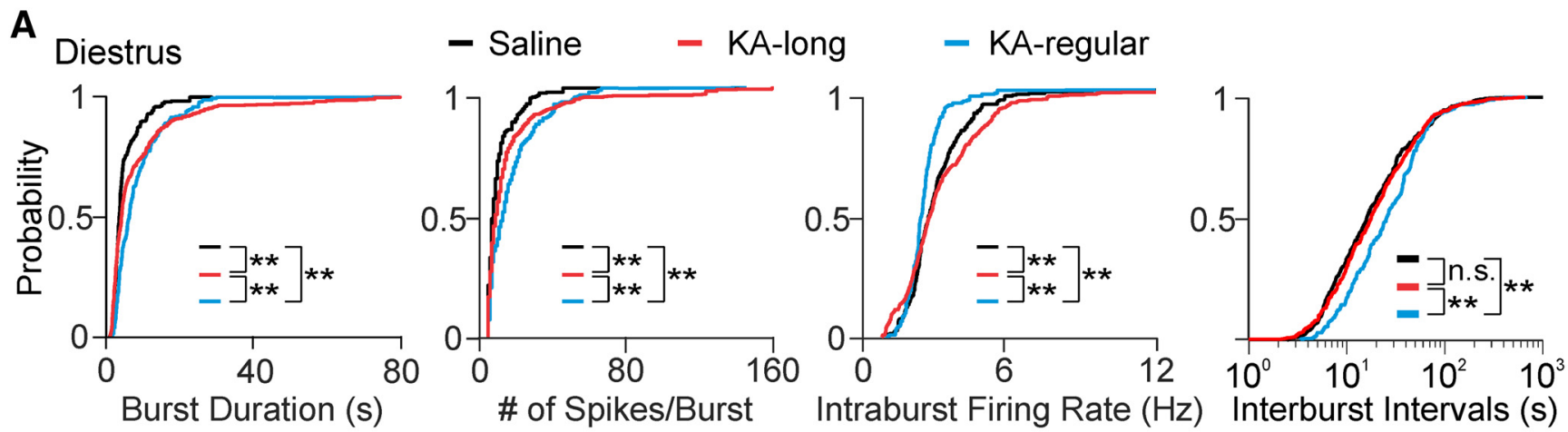

B
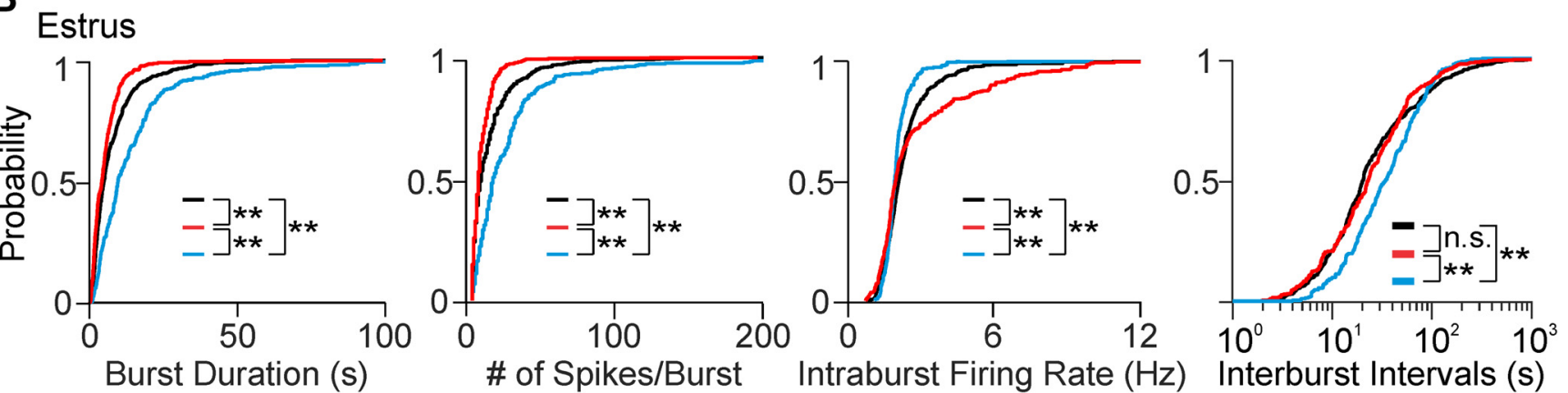

Figure 6. Bursting $\mathrm{GnRH}$ neurons from KA-injected female mice show changed burst properties. A, Cumulative probability distributions for burst properties in cells displaying bursting patterns from control (black traces), KA-long (red traces), and KA-regular (blue traces) mice recorded on diestrus. Cumulative distributions were constructed using 100 randomly selected bursts per cell. $\boldsymbol{B}$, Cumulative probability distributions for burst properties recorded on estrus; $* * p<0.01$ for comparisons between saline, KA-long, or KA-regular groups by pairwise Kolmogorov-Smirnov tests. n.s., not significant. The interburst intervals are presented on logarithmic scales for better visualization of the major portion (1-99\%) of the distributions.

diestrus $(p<0.0001$; Fig. $5 A$ ). GnRH neurons from KAlong females did not display the difference in burst duration and number of spikes per burst between cycle stages, but intraburst firing rate was decreased and interburst interval was longer on estrus than on diestrus (diestrus $n=10$ cells, estrus $n=10$ cells; both $p<0.0001$, pairwise Kolmogorov-Smirnov tests; Fig. 5B). GnRH neurons from KA-regular females showed the same directions of change as controls (diestrus $n=6$ cells, estrus $n=5$ cells), with increased burst duration, number of spikes per burst, and interburst interval, as well as decreased intraburst firing rate, on estrus compared with diestrus (all $p$ $<0.0001$, pairwise Kolmogorov-Smirnov tests; Fig. $5 C$ ). These results demonstrate that $\mathrm{GnRH}$ neuron burst properties fluctuate with the estrous cycle, showing changes indicative of increased bursting (and potentially increased hormone release) on estrus compared with diestrus.

On diestrus, cells from KA-injected mice showed increased burst duration and number of spikes per burst compared with controls (saline $n=8$ cells; KA-long $n=8$ cells; KA-regular $n=6$ cells; pairwise Kolmogorov-Smirnov tests: KA-long vs saline: $p<0.0001$, KA-regular vs saline: $p<0.0001$; Fig. $6 A$ ). The distributions of values for $\mathrm{KA}$-long and KA-regular groups, however, were also distinct from each other, with the KA-long group showing increased probability of the longest burst durations and highest numbers of spikes per burst $(p<0.0001)$. In comparison to controls, cells from KA-long females showed higher intraburst firing rates $(p<0.0001)$, but conversely, cells from KA-regular females showed decreased intraburst firing rates $(p<0.0001)$. In addition, the intervals between bursts were prolonged in $\mathrm{GnRH}$ neurons from KA-regular females compared with controls $(p=0.0006$; Fig. $6 A$ ), but cells from KA-long females did not show this difference. These latter findings of decreased intraburst firing rate and increased interburst interval in cells from KA-regular mice may represent compensatory mechanisms engaged to decrease burstdriven $\mathrm{GnRH}$ release in this group.

On estrus, GnRH neurons from KA-long females displayed shorter bursts, fewer spikes per burst, and higher intraburst firing rates than controls (saline $n=12$ cells; KA-long $n=10$ cells; all $p<0.0001$, pairwise Kolmogorov-Smirnov tests). GnRH neurons from KA-regular females ( $n=5$ cells), however, showed changes in the opposite direction, with longer burst duration, more spikes per burst, and slower intraburst firing rate than controls (all $p<0.0001$ ). GnRH neurons from KA-regular females also showed an altered distribution of interburst interval values compared to those from KA-long females and controls $(p<0.0001$; Fig. $6 B)$. These findings indicate that, although overall firing rates between cells from KAlong and KA-regular females are similar on estrus, the burst properties are quite different. Moreover, the burst properties of cells from KA-regular mice on estrus show the same pattern of differences compared with controls as observed on diestrus. For cells from KA-long mice, however, the effects on burst duration and number of 
A
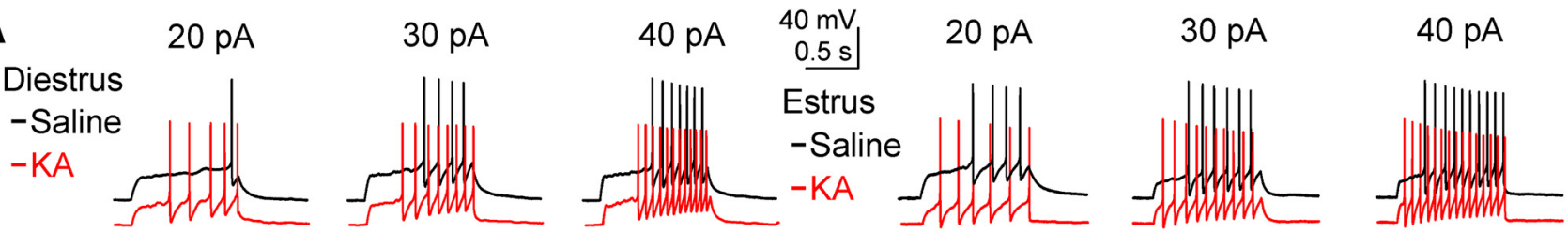

B

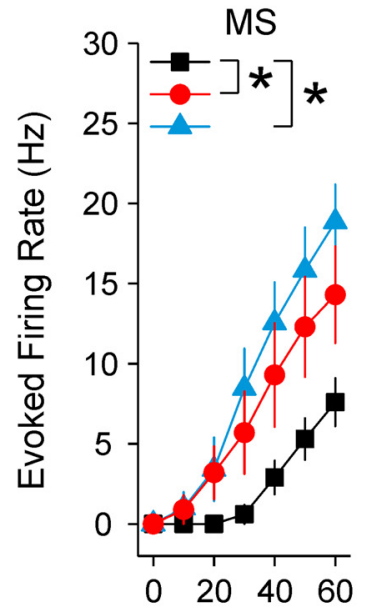

\section{Diestrus}
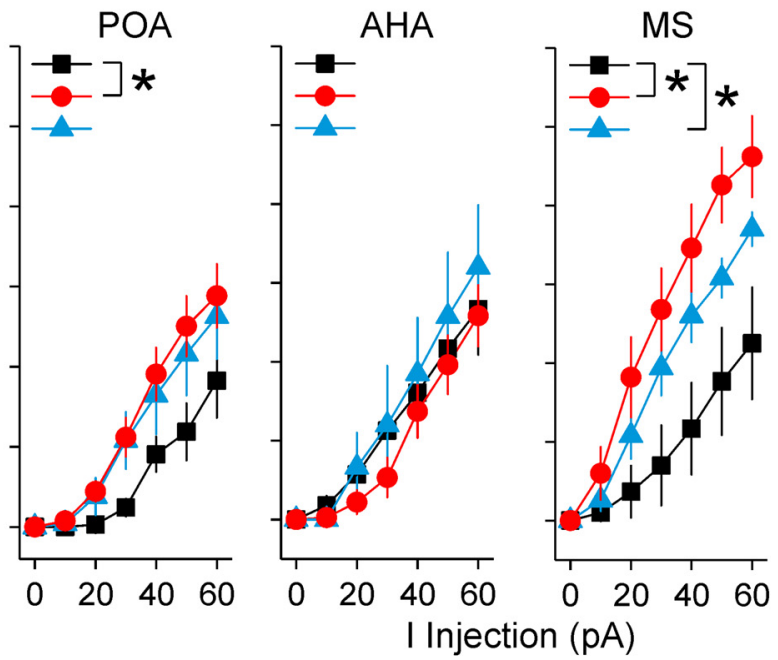

Estrus
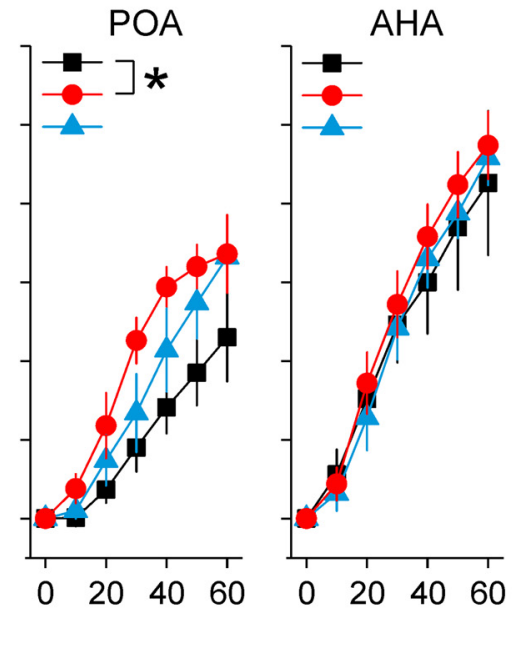

- Saline

I Injection (pA)

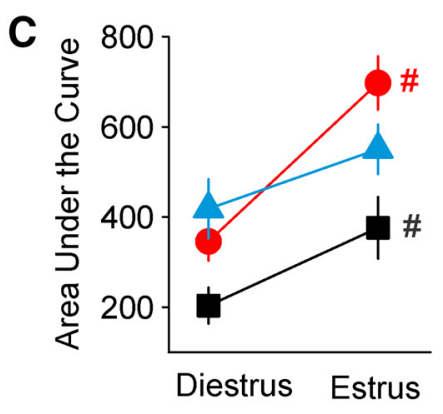

D
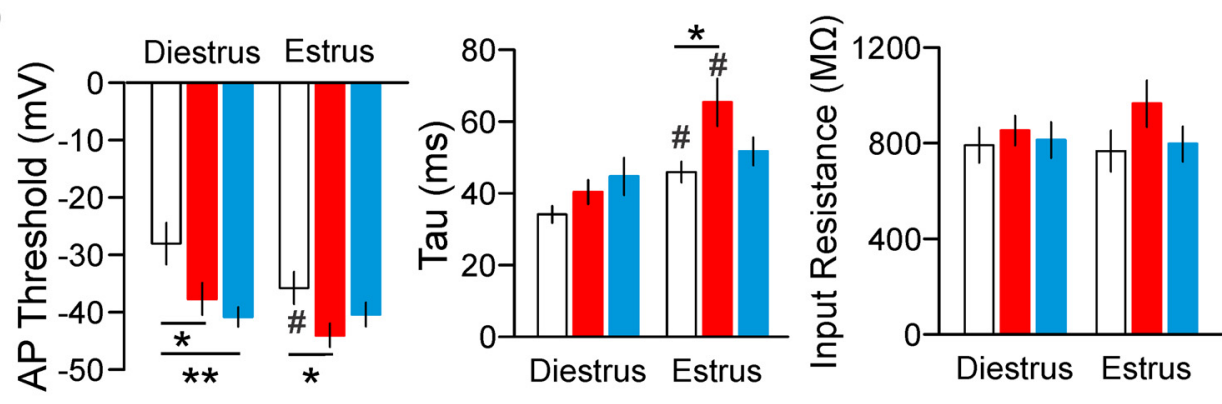

Saline

KA-long

KA-regular

Figure 7. GnRH neuron intrinsic excitability is elevated on both diestrus and estrus in the intrahippocampal KA mouse model of TLE. $\boldsymbol{A}$, Representative examples of evoked firing in response to depolarizing current steps in cells recorded on diestrus (left) and estrus (right). The KA traces are offset to highlight differences in spiking. All traces started from a membrane potential of approximately -73 $\mathrm{mV}$, corrected for the liquid junction potential. $\boldsymbol{B}$, Frequency-current (F-I) curves for $\mathrm{GnRH}$ neurons recorded on diestrus (left) or estrus (right), classified by the location of the somata of recorded neurons. Depolarizing current steps were applied in increments of $10 \mathrm{pA}$; $* p<0.05$ for comparisons of area under the curve by three-way ANOVA with Fisher's LSD. $\boldsymbol{C}$, Mean \pm SEM for area under the curve of evoked firing rate plots on diestrus and estrus in cells from control (black symbols and line), KA-long (red symbols and line), and KA-regular (blue symbols and line) mice. $\boldsymbol{D}$, Mean \pm SEM for AP threshold, membrane time constant $(\tau)$, and input resistance; $* p<$ $0.05, * * p<0.01$ by two-way ANOVA with Fisher's LSD; \#p $<0.05$ for comparisons between diestrus and estrus within groups by three-way ANOVA with Fisher's LSD.

spikes per burst on estrus in comparison to controls are opposite those observed on diestrus.

\section{GnRH neuron intrinsic excitability changes from diestrus to estrus and is persistently increased in $\mathrm{KA}$-injected female mice}

We used whole-cell current-clamp recordings to determine whether the observed changes in firing activity are associated with changes in intrinsic excitability. Threeway ANOVA showed treatment group, estrous cycle stage, and soma location all had effects on the GnRH neuron evoked firing rate (treatment group and estrous cycle: $p$ $<0.001$, soma location $p=0.019$ ). Neurons in the control group had higher evoked firing rates on estrus than on diestrus (diestrus $=18 \mathrm{cells} / 8$ mice, estrus $=20 \mathrm{cells} / 5$ mice, $p=0.005$, three-way ANOVA/Fisher's LSD; Fig. $7 A-C)$, indicating an endogenous increase in excitability on estrus compared with diestrus in control conditions.

Because there was no interaction between treatment group and estrous cycle stage $p=0.13$, overall three- 
way ANOVA), the data from diestrus and estrus were initially combined to examine the overall effects of $\mathrm{KA}$ injection on $\mathrm{GnRH}$ neuron excitability. In this analysis, $\mathrm{GnRH}$ neurons from both KA-long and KA-regular females showed increased excitability compared with controls (saline $n=38$ cells $/ 13$ mice, KA-long $n=41$ cells $/ 13$ mice, KA-regular $n=30$ cells $/ 11$ mice; saline vs KA-long, $p<0.001$, saline vs KA-regular, $p=0.001$; Fig. 7B,C). Furthermore, comparisons made examining each cycle stage separately identified elevated excitability in both $\mathrm{KA}$-injected groups compared with controls on both diestrus and estrus (diestrus: saline $n=18$ cells/8 mice, $\mathrm{KA}$-long $n=26$ cells $/ 8$ mice, KA-regular $n=15$ cells $/ 7$ mice; saline vs KA-long $p=0.047$, saline vs KA-regular $p$ $=0.008$, Fisher's LSD; estrus: saline $n=20$ cells $/ 5$ mice, $\mathrm{KA}$-long $n=15$ cells $/ 5$ mice, KA-regular $n=15$ cells $/ 4$ mice; saline vs KA-long $p<0.001$, saline vs KA-regular $p$ $=0.045$, Fisher's LSD). These results suggest that GnRH neuron intrinsic excitability is elevated in mice both with and without comorbid estrous cycle disruption after KA injection, and that this higher excitability persists across both diestrus and estrus.

Fisher's LSD post hoc tests were used to examine the differences between control and KA-injected groups with respect to soma location. Specifically, GnRH neurons from KA-long females in MS and POA, but not in AHA, showed increased excitability compared with controls at both cycle stages (MS $p=0.048$ diestrus, $p<0.001$ estrus; POA $p=0.021$ diestrus, $p=0.027$ estrus; $n=$ 5-13 cells for each group and location). Only GnRH neurons in MS from KA-regular females showed increased excitability compared with controls at both cycle stages (diestrus $p=0.003$, estrus $p=0.027 ; n=5-9$ cells for each location). No difference was observed between KAlong and KA-regular groups in either MS or POA, and no effect of KA injection was observed in the AHA region (Fig. $7 B$ ). These results suggest that, as with the effects on overall firing rate, $\mathrm{GnRH}$ neurons in the MS and POA show the greatest change in excitability after KA injection.

To investigate whether KA-injected females also showed cycle-stage-dependent fluctuations in $\mathrm{GnRH}$ neuron excitability as observed in the control mice, evoked firing rates from KA-injected mice were compared between diestrus and estrus. Cells from KA-long females showed higher excitability on estrus compared with diestrus $(p<0.001)$. Cells from KA-regular females showed a similar trend but not to the level of significance ( $p=0.067$; Fig. $7 C$ ). Together with the changes in burst firing specific to the KA-regular group described above, this trend may also represent a compensatory mechanism to bring intrinsic excitability values closer to the control range, particularly on estrus.

Additional excitability parameters were analyzed to evaluate potential mechanisms of increased $\mathrm{GnRH}$ neuron evoked firing rate observed in cells from KA-injected female mice. These parameters included AP threshold, input resistance, capacitance, membrane time constant $(\tau)$, latency to firing, ISI, and instantaneous frequency. Because cells in the MS and POA, but not AHA, showed changes in evoked firing rate, these excitability parameters were analyzed for MS and POA cells only. Three-way
ANOVA showed that the soma location did not affect any of the tested parameters. Therefore, the data from both MS and POA were grouped together for further analysis. On diestrus, neurons from KA-long and KA-regular females showed hyperpolarized AP threshold compared with controls $p=0.021 \mathrm{KA}$-long vs saline, $p<0.001$ KA-regular vs saline, two-way ANOVA/Fisher's LSD). On estrus, neurons from KA-long, but not KA-regular, females showed hyperpolarized AP threshold $(p=0.038$, two-way ANOVA/Fisher's LSD) and increased $\tau(p=$ 0.006, two-way ANOVA/Fisher's LSD) compared with controls (Fig. 7D). No differences were seen in input resistance or the other parameters (Fig. 7D; Table 3). None of the AP kinetics parameters examined (full-width at half-maximum, afterhyperpolarization amplitude, time to afterhyperpolarization, rise slope and decay slope) were different between control and KA-injected groups (Table 3). Together, these results indicate that the observed changes in overall intrinsic excitability are manifest most notably in hyperpolarized AP threshold on both diestrus and estrus, and increased membrane time constant on estrus. Furthermore, these effects are most prominent in $\mathrm{GnRH}$ neurons from KA-injected mice with more severe estrous cycle disruption.

Comparisons of $\mathrm{GnRH}$ neuron excitability parameters within groups between diestrus and estrus also indicated differences. AP threshold was hyperpolarized on estrus compared with diestrus in control mice $(p=0.022)$, but not in KA-long or KA-regular mice (KA-long $p=0.063$, KA-regular $p=0.9$ ); $\tau$ was increased on estrus compared with diestrus in control and KA-long mice (saline $p=$ 0.013 , KA-long $p<0.001$ ), but not in KA-regular mice ( $p$ $=0.12$; Fig. $7 D$ ). These results indicate that $\mathrm{KA}$-injected groups do not display the typical diestrus-to-estrus difference in AP threshold observed in controls. In addition, a lack of diestrus versus estrus difference in membrane time constant may represent another compensatory mechanism specific to the KA-regular group.

\section{Changes in circulating $P_{4}$ and $E_{2}$ levels two months after $\mathrm{KA}$ injection in females}

Changes in $\mathrm{GnRH}$ neuron activity could impact downstream gonadal function, including production and secretion of sex steroids. Reciprocally, sex steroid feedback can act at the hypothalamic level to affect $\mathrm{GnRH}$ neuron activity, and at the hippocampal level to modulate seizure susceptibility. Therefore, to determine whether circulating levels of the female sex steroid hormones $\mathrm{P}_{4}$ and $\mathrm{E}_{2}$ are altered in the intrahippocampal KA mouse model of TLE, we assayed trunk blood serum by ELISA. In controls, $\mathrm{P}_{4}$ levels were higher on estrus than on diestrus (diestrus = 23 mice, estrus $=18$ mice, $p=0.01$, two-sample $t$ test). In KA-long and KA-regular mice, $\mathrm{P}_{4}$ levels were not significantly different between diestrus and estrus (KA-long diestrus $n=19$ mice, estrus $n=10$ mice, $p>0.6$; KA-regular diestrus $n=20$ mice, estrus $n=7$ mice, $p=$ 0.14). Serum $\mathrm{P}_{4}$ levels were reduced in KA-long females compared with both controls and KA-regular females on both diestrus (KA-long vs saline $p=0.042$, KA-long vs KA-regular $p=0.02$; one-way ANOVA/Fisher's LSD) and 


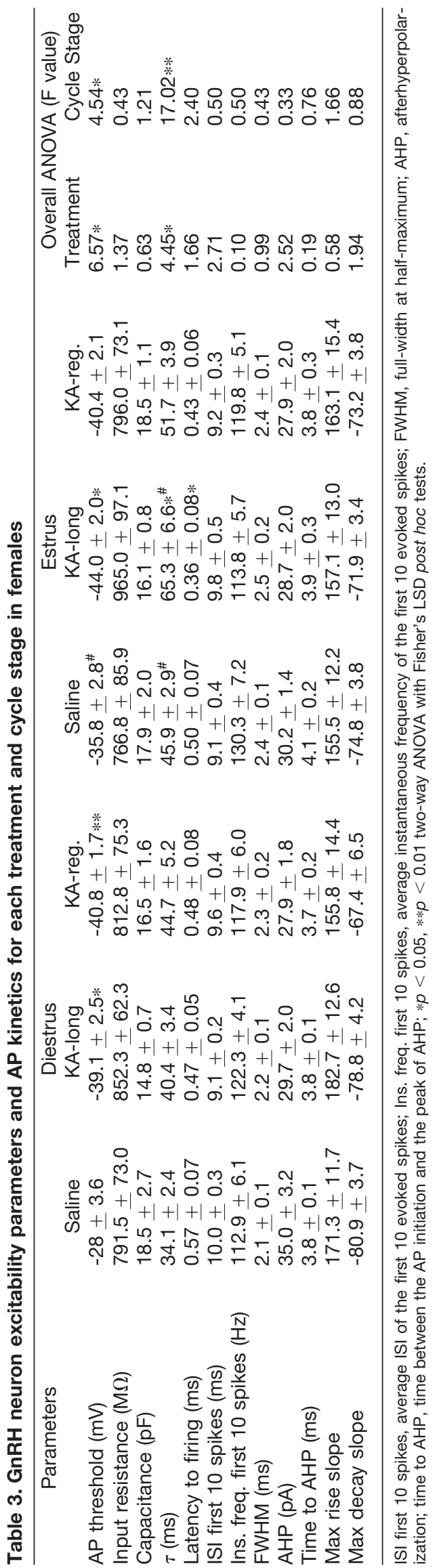

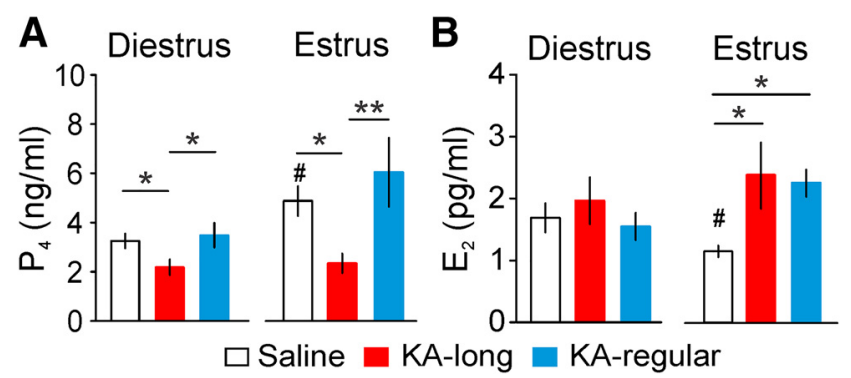

Figure 8. Changes in circulating $\mathrm{P}_{4}$ and $\mathrm{E}_{2}$ levels on diestrus and estrus as measured two months after KA injection. $\boldsymbol{A}$, Mean \pm SEM for $\mathrm{P}_{4}$ levels on diestrus (left) and estrus (right) in control (open bars), KA-long (red bars), and KA-regular (blue bars) mice. $\boldsymbol{B}$, Mean \pm SEM for $\mathrm{E}_{2}$ levels on diestrus (left) and estrus (right); $* p<0.05$ for comparisons between saline, KA-long, and KAregular groups by one-way ANOVA and Fisher's post hoc tests; $\# p<0.05$ for comparisons between estrus and diestrus within groups by $t$ tests.

estrus (KA-long vs saline $p=0.036$, KA-long vs KAregular $p=0.007$; one-way ANOVA/Fisher's LSD). $\mathrm{P}_{4}$ levels in KA-regular females were not different from controls at either cycle stage $(p>0.3$; Fig. $8 A)$. These results indicate that suppression of $\mathrm{P}_{4}$ levels on both diestrus and estrus is associated with increased severity of comorbid estrous cycle disruption after KA injection.

In control mice, serum $E_{2}$ levels were lower on estrus than diestrus (diestrus $=6$ mice, estrus $=6$ mice, $p=$ 0.035, two-sample $t$ test). In KA-long and KA-regular mice, the $E_{2}$ levels were not significantly different between diestrus and estrus (KA-long diestrus $n=8$ mice, estrus $n=10$ mice $p=0.59$; KA-regular diestrus $n=6$ mice, estrus $n=5$ mice $p=0.07$ ). On diestrus, $\mathrm{E}_{2}$ levels were not different between the three groups, but on estrus $E_{2}$ levels were significantly higher in KA-injected females compared with controls (KA-long vs saline $p=0.036$, KA-regular vs saline $p=0.016$; one-way ANOVA/Fisher's LSD), with no difference observed between KA-long and KA-regular females (Fig. 8B). These results indicate that $\mathrm{KA}$-injected mice both with and without comorbid estrous cycle disruption lack the typical decrease in $\mathrm{E}_{2}$ levels on estrus compared with diestrus.

\section{Male mice show modest disruption of GnRH neuron activity after KA treatment without changes in $\mathrm{T}$ levels}

An advantage of integrating mouse models of TLE with $\mathrm{GnRH}$-tdTomato mice is that we can also assess impacts of epilepsy on $\mathrm{GnRH}$ neurons from male mice, which lack a parameter akin to the estrous cycle that can be used as a high-throughput assay of reproductive endocrine comorbidities. To determine whether the effects of KA treatment on GnRH neurons are sex-specific, we measured firing rate, burst properties, and intrinsic excitability of GnRH neurons from control and KA-injected male mice at two months after surgery. There was not a change in overall mean firing rate between KA-injected and control groups (saline $n=18$ cells $/ 10$ mice, KA $n=25$ cells $/ 13$ mice, $p=0.14$; Fig. $9 A$ ), but comparison of mean firing rates based on soma location revealed that MS GnRH 

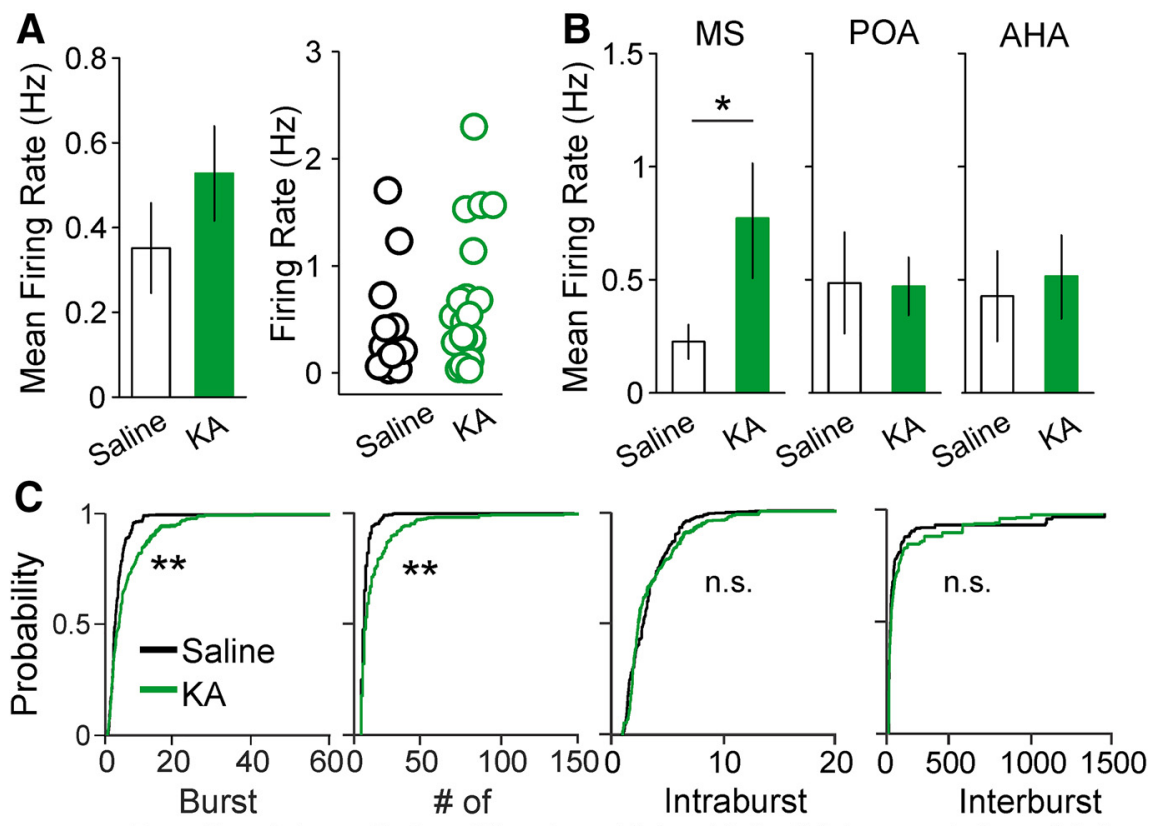

Duration (s) Spikes/Burst

Firing Rate $(\mathrm{Hz})$

Interval (s)
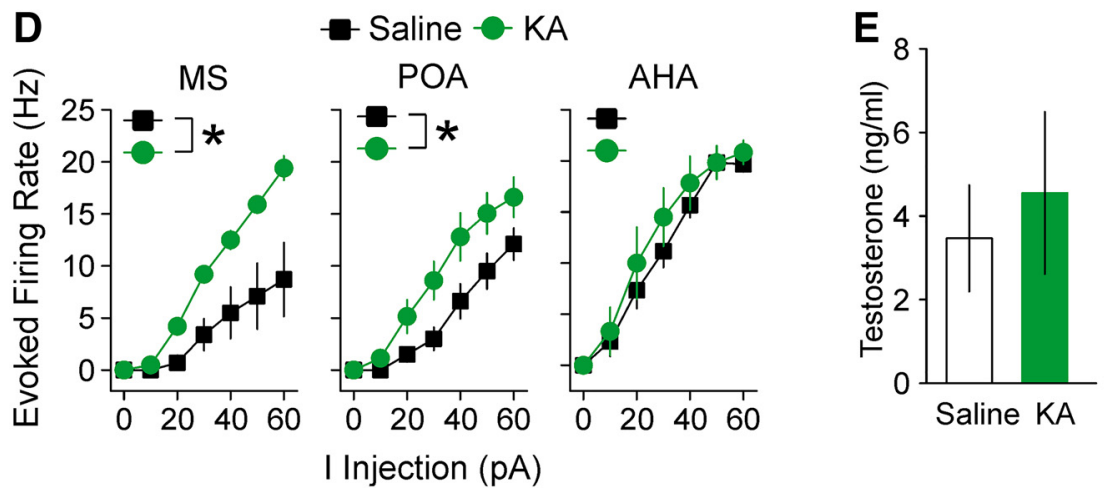

Figure 9. Impacts of KA injection on $\mathrm{GnRH}$ neuron mean firing rate and excitability in male mice depend on soma location. $\boldsymbol{A}$, Mean \pm SEM for mean firing rate (left) and firing rates for individual GnRH neurons (right) from males treated with saline (open bars and circles) or KA (green bars and circles). $\boldsymbol{B}$, Mean \pm SEM for mean firing rate of GnRH neurons from control and KA-injected males classified by soma location; $* p<0.05$, two-sample $t$ test. $\boldsymbol{C}$, Cumulative probability distributions for burst duration, number of spikes per burst, intraburst firing rate, and interburst intervals in cells from control and KA-injected males; $* * p<0.0001$ by KolmogorovSmirnov tests. $\boldsymbol{D}, \mathrm{F}$-I curves for GnRH neurons from control and KA-injected males; $* p<0.05$ for comparison of area under the curve by two-way ANOVA with Fisher's LSD post hoc tests. $\boldsymbol{E}$, Mean \pm SEM for serum T in control and KA-injected male mice.

neurons from KA-injected males displayed increased firing compared with controls (saline $n=5$ cells, $\mathrm{KA} n=7$ cells, $p=0.034$, Mann-Whitney test; Fig. 9B). Burst properties were altered, with longer burst duration and increased number of spikes per burst observed in the KAinjected group (saline $n=5$ cells, KA $n=6$ cells, both $p$ $<0.0001$, pairwise Kolmogorov-Smirnov tests; Fig. 9C). The saline-injected mice had bursting $\mathrm{GnRH}$ neurons in the POA (four neurons) and AHA (one neuron), whereas the KA-injected mice had bursting $\mathrm{GnRH}$ neurons in the POA (five neurons) and MS (one neuron). The intraburst firing rate and interburst interval were not different between control and KA-injected groups (Fig. 9C), and the proportion of $\mathrm{GnRH}$ neurons from male mice showing irregular spiking or bursting was not affected by KA treatment (control: $61 \%$ irregular and $39 \%$ bursting; KA-injected: $72 \%$ irregular and $28 \%$ bursting; $p>0.5, \chi^{2}$ test). No cells showed tonic spiking or quiet patterns. These results suggest that the impacts of $\mathrm{KA}$ injection on $\mathrm{GnRH}$ neuron firing are different in males compared with females.

In whole-cell current-clamp recordings, $\mathrm{GnRH}$ neurons in the MS and POA from KA-injected males showed higher evoked firing rates compared with controls (MS $p=0.028$, POA $p=0.044$, two-way ANOVA/Fisher's LSD; $n=5-10$ cells for each group and location; Fig. 9D). Cells in the AHA did not show a KA-induced difference in excitability. No other parameters of excitability and AP kinetics were different between control and KA-injected males (Table 4). These results indicate that, as observed in females, excitability of MS and POA GnRH neurons is elevated in KA-injected males, although the change in excitability is limited to evoked firing rate. In addition, serum $\mathrm{T}$ levels in $\mathrm{KA}$-injected males were not different from controls (Fig. 9E). 
Table 4. GnRH neuron excitability parameters and AP kinetics for saline and KA-injected males

\begin{tabular}{lll}
\hline Parameters & Saline & KA \\
AP threshold (mV) & $-40.6 \pm 2.9$ & $-42.3 \pm 2.3$ \\
Input resistance $(\mathrm{M} \Omega)$ & $745.6 \pm 36.9$ & $1892.2 \pm 984.2$ \\
Capacitance $(\mathrm{pF})$ & $16.7 \pm 1.0$ & $15.7 \pm 1.0$ \\
$\tau(\mathrm{ms})$ & $51.0 \pm 3.7$ & $61.7 \pm 6.5$ \\
Latency to firing (ms) & $628.1 \pm 67.2$ & $493.5 \pm 68.6$ \\
ISI first 10 spikes (ms) & $123.4 \pm 5.4$ & $121.4 \pm 3.7$ \\
Ins. freq. first 10 spikes (Hz) & $9.9 \pm 1.2$ & $9.9 \pm 0.5$ \\
FWHM (ms) & $2.3 \pm 0.12$ & $2.4 \pm 0.3$ \\
AHP & $31.6 \pm 2.6$ & $32.8 \pm 1.9$ \\
Time to AHP & $3.6 \pm 0.1$ & $3.5 \pm 0.2$ \\
Max rise slope & $187.3 \pm 11.7$ & $158.9 \pm 3.2$ \\
Max decay slope & $-77.5 \pm 5.1$ & $-75.3 \pm 4.2$
\end{tabular}

ISI first 10 spikes: average ISI of the first 10 evoked spikes; Ins. freq. first 10 spikes, average instantaneous frequency of the first 10 evoked spikes; FWHM, full-width at half-maximum; AHP, afterhyperpolarization; time to AHP, time between the AP initiation and the peak of AHP. Two-sample $t$ tests for each parameter did not identify any differences between controls and KA-injected groups.

\section{Discussion}

Pathologies in the neural control of reproduction likely link epilepsy and comorbid reproductive endocrine disorders, but specific functional changes in key neuronal populations regulating reproduction and fertility, including $\mathrm{GnRH}$ neurons, have not been described. The present studies provide direct evidence for changes in $\mathrm{GnRH}$ neuron function with epilepsy, and indicate that impacts on $\mathrm{GnRH}$ neuron function are associated with severity of comorbid estrous cycle disruption, different on diestrus compared with estrus, and sex-specific. Overall, GnRH neurons from KA-injected diestrous females, estrous females, and males shared some commonalities as well as some group-specific changes. GnRH neurons in the MS and POA showed increased evoked firing rates across all groups, but only females showed significantly hyperpolarized AP threshold. In addition, these results are the first to show that unilateral KA injection alters circulating sex hormone levels in female mice. Due to the complex feedback loops involved, it remains difficult at present to distinguish changes that are direct consequences of epileptiform activity in the hippocampus from those that are secondary alterations that develop as a feedback response to comorbid estrous cycle disruption. The changes common to all groups, however, likely reflect the direct consequences of KA-induced epilepsy.

\section{Linking hippocampal seizure activity to changes in hypothalamic GnRH neuron function}

Seizures in TLE originate primarily in the hippocampus and rarely become generalized (Engel, 1996). The intrahippocampal KA mouse model of TLE similarly shows recurrent spontaneous paroxysmal discharges mainly restricted to the vicinity of the injected hippocampal area (Riban et al., 2002), although recent work using cortical surface recordings in the same model detected generalized spikes propagating across frontal cortices as well (Sheybani et al., 2018). Whether there is a correlation between hippocampal seizure burden and temporal proximity of recent seizure activity to $\mathrm{GnRH}$ neuron functional abnormalities and estrous cycle disruption will be investigated by incorporating electroencephalogram recordings in future studies. In this regard, spontaneous seizures in the intrahippocampal KA mouse model are present by approximately two weeks after KA injection (Riban et al., 2002; Heinrich et al., 2011), whereas the estrous cycle disruption in this model does not emerge until approximately six weeks after KA injection (Li et al., 2017). This time course indicates that the robust pattern of disrupted estrous cyclicity develops gradually after epilepsy is fully established, perhaps reflecting a cumulative effect of seizure burden over time (Raedt et al., 2009). This temporal sequence should provide important insights in future studies about the causal relationships between epileptogenesis, seizure severity, GnRH neuron pathology, and estrous cycle disruption.

Focal hippocampal seizures could potentially affect GnRH neurons through direct and/or indirect projections between the hippocampus and the hypothalamus. Indeed, it has long been known that electrical stimulation in hippocampus can reduce gonadotropin release and prevent ovulation, indicating functional links between the hippocampus and hypothalamic circuits for reproduction (Velasco and Taleisnik, 1969; Gallo et al., 1971). The present data indicate that $\mathrm{GnRH}$ neurons with aberrant firing activity in females are primarily located in the MS and POA. Similarly, the MS is the only region that contained $\mathrm{GnRH}$ neurons with increased firing rates in male mice, although cells in the POA showed altered bursting properties. There are robust bidirectional projections between the hippocampus and the MS (Gaykema et al., 1991; Mattis et al., 2014). The prominence of KA-induced changes in GnRH neurons located in the MS suggests that these pathways may provide anatomic substrates for seizure activity and/or the secondary consequences of hippocampal epileptiform activity to propagate and impact hypothalamic $\mathrm{GnRH}$ neurons. The extent and characteristics of reorganization of hippocampal projections to $\mathrm{GnRH}$ neuron circuitry following intrahippocampal KA injection remain unclear. Furthermore, GnRH neurons form a heterogeneous population with variations, for example, in firing properties (Constantin et al., 2013), neuromodulator receptor expression (Jasoni et al., 2005), and participation in the preovulatory $\mathrm{GnRH} / \mathrm{LH}$ surge (Hoffman et al., 1993; Wintermantel et al., 2006; Christian and Moenter, 2007) associated with differences in soma location. The relationship between the anatomic location of $\mathrm{GnRH}$ neuron somata and cellular heterogeneity has not yet been fully characterized, but the present data support a working model in which the location of the $\mathrm{GnRH}$ neuron soma helps to shape the functional outcome in the face of epilepsy, in concert with changes in hippocampalhypothalamic projections differentially targeting the MS, $\mathrm{POA}$, and AHA.

\section{Pathologic hallmarks of TLE in hippocampus and hypothalamus}

Hippocampal sclerosis is a common hallmark of TLE in humans (Margerison and Corsellis, 1966; Cook et al., 1992; Blümcke et al., 2013; Blumcke et al., 2017). The 
intrahippocampal KA mouse model of TLE reproduces this hippocampal sclerosis in multiple ways, including extensive neuronal loss, gliosis, and hippocampal circuit reorganization. Specifically, the complete degeneration of CA1 and CA3 is often observed in ipsilateral dorsal hippocampus, along with enlargement of the dentate granule cell layer (Bouilleret et al., 1999; Riban et al., 2002; Fig. $2 A)$. Although intrahippocampal KA injection induces acute injury and cell loss, it should be noted that estrous cyclicity can persist following complete ablation of the hippocampus in rats (Terasawa and Kawakami, 1973). Furthermore, we observed similar rates of hippocampal sclerosis induction in both KA-long and KA-regular groups. Therefore, the changes observed in $\mathrm{GnRH}$ neuron function likely reflect epileptic circuit reorganization and downstream propagating effects of seizure activity, rather than acute effects of the initial precipitating hippocampal injury per se (i.e., effects independent of epileptiform activity). The extent of hypothalamic pathology in the intrahippocampal KA mouse model used here remains unclear. However, neither cell loss nor gliosis were observed in the hypothalamus in a unilateral KA macaque model of epilepsy (Chen et al., 2013), and no GnRH neuron cell loss was observed in a systemic pilocarpine mouse model (Fawley et al., 2012).

\section{Changes in GnRH neuron firing properties: potential links to downstream HPG axis malfunction}

Changes in LH pulse frequency have been reported in women with epilepsy in the absence of antiepileptic drug treatment, even when regular menstrual cyclicity is maintained (Bilo et al., 1991; Meo et al., 1993). Altered $\mathrm{GnRH}-\mathrm{LH}$ release in patients with epilepsy may thus represent a form of subclinical reproductive dysfunction. Because hormone secretion by neuroendocrine cells, such as vasopressin and oxytocin neurons, has long been linked with burst firing activities (Wakerley and Lincoln, 1973; Dutton and Dyball, 1979), we examined whether KA injection affected $\mathrm{GnRH}$ neuron firing patterns and/or burst properties. Although the proportions of cells showing burst firing were not altered following KA injection, there were significant differences in burst properties in cells from both KA-injected male and female mice. Moreover, the changes observed in KA-injected female mice were distinct depending on whether estrous cycles were of regular or long length, indicating that changes in $\mathrm{GnRH}$ neuron burst patterning differ with the severity of the comorbidity. High and low GnRH pulse frequency favors the pituitary synthesis and release of $\mathrm{LH}$ and folliclestimulating hormone, respectively (Wildt et al., 1981), but the effect of $\mathrm{GnRH}$ pulse duration (perhaps reflected in burst duration) on gonadotropin release is still unknown. In addition, the aberrant presence of tonic spiking neurons on diestrus and quiet neurons on estrus could potentially impair overall $\mathrm{GnRH}$ neuron network communication and rhythmicity. In this regard, GnRH neurons express $\mathrm{GnRH}$ receptors and the firing activity of $\mathrm{GnRH}$ neurons changes in response to application of GnRH (Xu et al., 2004; Todman et al., 2005; Han et al., 2010). At the pituitary level, higher rates of $\mathrm{GnRH}$ neuron firing activity may also give rise to sustained elevations in GnRH content in the pituitary vasculature, which could downregulate the pituitary response to GnRH (Belchetz et al., 1978; Smith et al., 1983). Further studies are thus needed to determine whether altered $\mathrm{GnRH}$ neuron firing patterns drive dysregulated $\mathrm{GnRH}$ and gonadotropin secretion in epilepsy.

On diestrus, there was a moderate but significant correlation between $\mathrm{GnRH}$ neuron firing rate and estrous cycle length in KA-injected mice, indicating a relationship between elevated $\mathrm{GnRH}$ neuron activity and the severity of the estrous cycle comorbidity. The estrous cycle is regulated by a complex interplay involving hypothalamic $\mathrm{GnRH}$ release, pituitary gonadotropin release, and ovarian response. Although it is unknown whether $\mathrm{LH}$ or $\mathrm{FSH}$ release is altered in this model of epilepsy, the ovaries do not show major histopathological changes at two months after KA injection ( $\mathrm{Li}$ et al., 2017), indicating that the estrous cycle phenotype is not reflective of gross ovarian damage. Therefore, although it would be premature to directly link the changes in $\mathrm{GnRH}$ neuron mean firing rate to the effects on estrous cyclicity, the positive correlation observed indicates that changes in $\mathrm{GnRH}$ neuron activity, and potentially downstream pituitary gonadotropin release, are likely to be major players in this comorbidity.

\section{Relationships of sex steroid feedback and epilepsy- associated changes in GnRH neuron activity}

Changes in GnRH neuron firing could be, at least in part, the consequences of altered sex hormone feedback. $\mathrm{P}_{4}$ typically exerts strong suppression of $\mathrm{GnRH}$ neuron activity (Pielecka et al., 2006; Bashour and Wray, 2012) and GnRH release (Goodman and Karsch, 1980; Leipheimer et al., 1984; He et al., 2017). Our finding of decreased $\mathrm{P}_{4}$ levels (and the likely reduction of $\mathrm{P}_{4}$ negative feedback) in KA-long females on diestrus is thus consistent with the increased mean firing rate observed in this group. $\mathrm{P}_{4}$ levels were also reduced in KA-long females on estrus, but this change is not consistent with the significantly suppressed firing rate of $\mathrm{GnRH}$ neurons from this group at this stage, suggesting other mechanisms are likely involved. $\mathrm{P}_{4}$ may still play a role in driving suppressed firing in KA-regular females on estrus, however, as this group did not show a reduction in circulating $\mathrm{P}_{4}$.

On both diestrus and estrus, $E_{2}$ levels were within the low physiologic range in which $E_{2}$ typically exerts negative (i.e., suppressive) feedback on $\mathrm{GnRH}$ release (Sarkar and Fink, 1980; Evans et al., 1994). Control mice had higher $E_{2}$ levels on diestrus compared to estrus. This result is in line with the lower $\mathrm{GnRH}$ neuron firing rate on diestrus, although an alternative possibility is that the boost in $\mathrm{GnRH}$ neuron firing rate observed on early estrus reflects the tail end of the robust increase in firing activity that drives the preovulatory $\mathrm{GnRH}$ surge during late proestrus (Christian and Moenter, 2010). Furthermore, the increased $E_{2}$ levels on estrus in both KA-long and KA-regular females would be predicted to exert increased negative feedback on $\mathrm{GnRH}$ neurons, and are thus consistent with the decreased $\mathrm{GnRH}$ neuron firing rate observed at this cycle 
stage in both groups. Serum $E_{2}$ levels on diestrus were similar between KA-injected and control females, suggesting that $E_{2}$ does not contribute to the observed increase in $\mathrm{GnRH}$ neuron firing on diestrus in the KA-long group. These differences in circulating $\mathrm{P}_{4}$ and $\mathrm{E}_{2}$ levels could reflect altered ovarian steroidogenesis and/or compromised metabolism of sex steroids by peripheral cytochrome P450 oxidases (Runtz et al., 2018). Mechanistic investigation of the roles of $E_{2}$ and $P_{4}$ feedback in mediating epilepsy-associated changes in $\mathrm{GnRH}$ neuron function will be an important aspect of future study, for example through selective hormone replacement in gonadectomized mice, or incorporation of mouse models in which specific steroid hormone receptors are absent or not functional.

Alterations in circulating steroid levels could also exert impacts at the level of hippocampus to modulate seizure activity. For example, central $\mathrm{P}_{4}$ conversion to the neurosteroid allopregnanolone can reduce seizure susceptibility and epileptiform activity through potent positive allosteric modulation of hippocampal $\mathrm{GABA}_{A}$ receptors (Maguire et al., 2005; Lawrence et al., 2010; Reddy and Rogawski, 2012). Therefore, reduced $\mathrm{P}_{4}$ levels in the KAlong mice may also be indicative of reduced neurosteroid production in the brain, which could exacerbate seizure activity in this group.

In a study examining the systemic pilocarpine model of TLE in female rats, circulating $T$ was elevated concomitant with the presence of cystic ovaries (Scharfman et al., 2008). In the present studies, measurement of $T$ in the females was inconclusive because the serum amounts that remained after completing the assays for $\mathrm{P}_{4}$ and $\mathrm{E}_{2}$ were too small to be reliably assayed in duplicate. However, it should be noted that many values were below the ELISA detection limit, and those samples that did yield values were not different between control and KA-injected mice (unpublished observations). Together, these results suggest that circulating $T$ was not elevated in the KAinjected female mice. This finding is consistent with previous work in which ovarian cysts were not observed in this mouse model of TLE (Li et al., 2017), and thus elevated $T$ levels would not be expected.

Of note, the pattern of changes in $E_{2}$ and $P_{4}$ levels detected in this mouse model does not directly match changes in sex steroid levels reported in a limited number of human clinical studies (Herzog et al., 2003; Kalinin and Zheleznova, 2007). Human TLE, however, is a more heterogeneous condition than one animal model can reproduce. The location of seizure origin, the effects of different anti-epileptic drugs, and timing of hormone level measurement in relation to menstrual cycle stage could all profoundly influence the phenotype of changes in sex steroid levels induced by epilepsy. Further exploration of neuroendocrine disruption in both the clinic and in preclinical models is needed to elucidate the spectrum of changes that can be induced by epilepsy and seizure activity, and to determine differential mechanisms that may drive these varying outcomes.

\section{Relative contributions of GnRH neuron intrinsic excitability and synaptic inputs in driving epilepsy- associated changes in GnRH neuron activity}

In contrast to the bidirectional changes in $\mathrm{GnRH}$ neuron firing rate observed in KA-injected female mice, intrinsic excitability was persistently elevated in KA-injected groups on both diestrus and estrus, and irrespective of estrous cycle period phenotype. Hyperpolarized AP threshold was the most prominent change observed in cells from KA-injected females. Tetrodotoxin-sensitive voltage-gated sodium channels control the AP depolarization in GnRH neurons (Norberg et al., 2013), and therefore may play important roles in determining AP threshold. $\mathrm{GnRH}$ neuron AP threshold and latency to firing can also be modulated by $E_{2}$ feedback, for example through A-type potassium currents (DeFazio and Moenter, 2002). Changes in these and other underlying conductances likely shape the overall shifts in excitability produced both across estrous cycle stages and in response to epilepsy. In addition, the persistent increase in excitability of $\mathrm{GnRH}$ neurons from KA-injected mice, together with the dynamic changes in mean firing rate, indicate that afferent synaptic and/or neuromodulatory inputs likely play a role in shaping the cycle-stage-dependent shifts in overall firing behavior. In this regard, most $E_{2}$ and $P_{4}$ feedback to $\mathrm{GnRH}$ neurons is mediated trans-synaptically (Sullivan and Moenter, 2005; Wintermantel et al., 2006; Christian and Moenter, 2007), and certainly at least one synaptic connection is needed to transmit the effects of hippocampal seizure activity to hypothalamic GnRH neurons. It will be interesting in future studies to determine which steroid hormone-sensitive and hormone-insensitive pathways are involved in transmitting the effects of seizure activity to $\mathrm{GnRH}$ neurons, and in driving differential changes dependent on estrous cycle stage.

\section{Concluding remarks}

The present results provide novel direct evidence of aberrant $\mathrm{GnRH}$ neuron activity and excitability in an animal model of epilepsy. Most importantly, this study supports a model in which the pattern of changes in GnRH neuron firing activity in epilepsy is not a fixed property, but is profoundly influenced by the overall physiologic state. Furthermore, these studies emphasize the utility of this model of TLE in distinguishing which changes are observed concomitant with estrous cycle disruption, and which changes are observed in resilient females that maintain regular estrous cyclicity. These findings thus have important implications for further studies of the neural mechanisms linking epilepsy to comorbid reproductive endocrine dysfunction, and provide an indication that treatment strategies for both seizures and reproductive comorbidities need to be tailored based on cycle stage, comorbidity severity, and sex.

\section{References}

Amado D, Verreschi IT, Berzaghi MP, Cavalheiro EA (1987) Effects of intrahippocampal injection of kainic acid on estrous cycle in rats. Braz J Med Biol Res 20:829-832. Medline

Amado D, Cavalheiro E, Bentivoglio M (1993) Epilepsy and hormonal regulation: the patterns of $\mathrm{GnRH}$ and galanin immunoreactivity in 
the hypothalamus of epileptic female rats. Epilepsy Res 14:149159. Medline

Amado D, Cavalheiro E (1998) Hormonal and gestational parameters in female rats submitted to the pilocarpine model of epilepsy. Epilepsy Res 32:266-274. CrossRef

Bashour NM, Wray S (2012) Progesterone directly and rapidly inhibits $\mathrm{GnRH}$ neuronal activity via progesterone receptor membrane component 1. Endocrinology 153:4457-4469. CrossRef Medline

Bauer J, Jarre A, Klingmüller D, Elger CE (2000) Polycystic ovary syndrome in patients with focal epilepsy: a study in 93 women. Epilepsy Res 41:163-167. Medline

Bauer J, Cooper-Mahkorn D (2008) Reproductive dysfunction in women with epilepsy: menstrual cycle abnormalities, fertility, and polycystic ovary syndrome. Int Rev Neurobiol 83:135-155. CrossRef Medline

Belchetz PE, Plant TM, Nakai Y, Keogh EJ, Knobil E (1978) Hypophysial responses to continuous and intermittent delivery of hypopthalamic gonadotropin-releasing hormone. Science 202:631633. Medline

Bilo L, Meo R, Valentino R, Buscaino GA, Striano S, Nappi C (1991) Abnormal pattern of luteinizing hormone pulsatility in women with epilepsy. Fertil Steril 55:705-711. Medline

Bilo L, Meo R, Valentino R, Di Carlo C, Striano S, Nappi C (2001) Characterization of reproductive endocrine disorders in women with epilepsy. J Clin Endocrinol Metab 86:2950-2956. CrossRef Medline

Blümcke I, Thom M, Aronica E, Armstrong DD, Bartolomei F, Bernasconi A, Bernasconi N, Bien CG, Cendes F, Coras R (2013) International consensus classification of hippocampal sclerosis in temporal lobe epilepsy: a task force report from the ILAE Commission on Diagnostic Methods. Epilepsia 54:1315-1329. CrossRef Medline

Blumcke I, Spreafico R, Haaker G, Coras R, Kobow K, Bien CG, Pfäfflin M, Elger C, Widman G, Schramm J, Becker A, Braun KP, Leijten F, Baayen JC, Aronica E, Chassoux F, Hamer H, Stefan H, Rössler K, Thom M, et al. (2017) Histopathological findings in brain tissue obtained during epilepsy surgery. N Engl J Med 377:16481656. CrossRef Medline

Bouilleret V, Ridoux V, Depaulis A, Marescaux C, Nehlig A, La Salle GLG (1999) Recurrent seizures and hippocampal sclerosis following intrahippocampal kainate injection in adult mice: electroencephalography, histopathology and synaptic reorganization similar to mesial temporal lobe epilepsy. Neuroscience 89:717-729. CrossRef

Byers SL, Wiles MV, Dunn SL, Taft RA (2012) Mouse estrous cycle identification tool and images. PLoS One 7:e35538. CrossRef Medline

Chen N, Liu C, Yan N, Hu W, Zhang JG, Ge Y, Meng FG (2013) A macaque model of mesial temporal lobe epilepsy induced by unilateral intrahippocampal injection of kainic acid. PLoS One 8:e72336. CrossRef Medline

Christian CA, Mobley JL, Moenter SM (2005) Diurnal and estradioldependent changes in gonadotropin-releasing hormone neuron firing activity. Proc Natl Acad Sci USA 102:15682-15687. CrossRef Medline

Christian CA, Moenter SM (2007) Estradiol induces diurnal shifts in GABA transmission to gonadotropin-releasing hormone neurons to provide a neural signal for ovulation. J Neurosci 27:1913-1921. CrossRef Medline

Christian CA, Moenter SM (2010) The neurobiology of preovulatory and estradiol-induced gonadotropin-releasing hormone surges. Endocr Rev 31:544-577. CrossRef Medline

Christian CA (2017) Neurophysiology of gonadotropin-releasing hormone neurons. In: Hormones, brain and behavior, Ed 3 (Pfaff DW, Joëls M, eds), pp 379-400. Oxford: Academic Press.

Constantin S, Iremonger KJ, Herbison AE (2013) In vivo recordings of $\mathrm{GnRH}$ neuron firing reveal heterogeneity and dependence upon GABAA receptor signaling. J Neurosci 33:9394-9401. CrossRef Medline
Cook MJ, Fish DR, Shorvon SD, Straughan K, Stevens JM (1992) Hippocampal volumetric and morphometric studies in frontal and temporal lobe epilepsy. Brain 115:1001-1015. CrossRef

DeFazio RA, Moenter SM (2002) Estradiol feedback alters potassium currents and firing properties of gonadotropin-releasing hormone neurons. Mol Endocrinol 16:2255-2265. CrossRef Medline

Dodla R, Wilson CJ (2010) Quantification of clustering in joint interspike interval scattergrams of spike trains. Biophys J 98:25352543. CrossRef Medline

Drislane F, Coleman A, Schomer D, Ives J, Levesque L, Seibel M, Herzog A (1994) Altered pulsatile secretion of luteinizing hormone in women with epilepsy. Neurology 44:306-306. Medline

Dutton A, Dyball RE (1979) Phasic firing enhances vasopressin release from the rat neurohypophysis. J Physiol 290:433-440. Medline

Edwards HE, Burnham WM, Ng MM, Asa S, MacLusky NJ (1999) Limbic seizures alter reproductive function in the female rat. Epilepsia 40:1370-1377. Medline

Edwards H, MacLusky N, Burnham W (2000) The effect of seizures and kindling on reproductive hormones in the rat. Neurosci Biobehav Rev 24:753-762. Medline

Engel J (1996) Introduction to temporal lobe epilepsy. Epilepsy Res 26:141-150. Medline

Engel J Jr (2001) Mesial temporal lobe epilepsy: what have we learned? Neuroscientist 7:340-352. CrossRef Medline

Evans NP, Dahl GE, Glover BH, Karsch FJ (1994) Central regulation of pulsatile gonadotropin-releasing hormone $(\mathrm{GnRH})$ secretion by estradiol during the period leading up to the preovulatory $\mathrm{GnRH}$ surge in the ewe. Endocrinology 134:1806-1811. CrossRef Medline

Fawley J, Pouliot W, Dudek FE (2012) Pilocarpine-induced status epilepticus and subsequent spontaneous seizures: lack of effect on the number of gonadotropin-releasing hormone-positive neurons in a mouse model of temporal lobe epilepsy. Neuroscience 203:153-159. CrossRef

Finn DA, Gee KW (1994) The estrus cycle, sensitivity to convulsants and the anticonvulsant effect of a neuroactive steroid. J Pharmacol Exp Ther 271:164-170. Medline

Fox JG, Barthold S, Davisson M, Newcomer CE, Quimby FW, Smith A (2006) The mouse in biomedical research: normative biology, husbandry, and models. San Diego: Academic Press.

Friedman M, Geula C, Holmes G, Herzog A (2002) GnRHimmunoreactive fiber changes with unilateral amygdala-kindled seizures. Epilepsy Res 52:73-77. Medline

Gallo R, Johnson J, Goldman B, Whitmoyer D, Sawyer C (1971) Effects of electrochemical stimulation of the ventral hippocampus on hypothalamic electrical activity and pituitary gonadotropin secretion in female rats. Endocrinology 89:704-713. CrossRef Medline

Gaykema R, Van der Kuil J, Hersh L, Luiten P (1991) Patterns of direct projections from the hippocampus to the medial septumdiagonal band complex: anterograde tracing with Phaseolus vulgaris leucoagglutinin combined with immunohistochemistry of choline acetyltransferase. Neuroscience 43:349-360. Medline

Goodman RL, Karsch FJ (1980) Pulsatile secretion of luteinizing hormone: differential suppression by ovarian steroids. Endocrinology 107:1286-1290. CrossRef Medline

Han SK, Lee K, Bhattarai JP, Herbison AE (2010) Gonadotrophinreleasing hormone $(\mathrm{GnRH})$ exerts stimulatory effects on $\mathrm{GnRH}$ neurons in intact adult male and female mice. J Neuroendocrinol 22:188-195. CrossRef Medline

He W, Li X, Adekunbi D, Liu Y, Long H, Wang L, Lyu Q, Kuang Y, O'Byrne KT (2017) Hypothalamic effects of progesterone on regulation of the pulsatile and surge release of luteinising hormone in female rats. Sci Rep 7:8096. CrossRef Medline

Heinrich C, Lähteinen S, Suzuki F, Anne-Marie L, Huber S, Häussler U, Haas C, Larmet Y, Castren E, Depaulis A (2011) Increase in BDNF-mediated TrkB signaling promotes epileptogenesis in a mouse model of mesial temporal lobe epilepsy. Neurobiol Dis 42:35-47. CrossRef 
Herbison AE (2006) Physiology of the gonadotropin-releasing hormone neuronal network. In: Knobil and Neill's physiology of reproduction, Ed 3 (Neill JD, ed), pp 1415-1482. New York: Raven Press.

Herzog AG, Seibel MM, Schomer DL, Vaitukaitis JL, Geschwind N (1986a) Reproductive endocrine disorders in women with partial seizures of temporal lobe origin. Arch Neurol 43:341-346.

Herzog AG, Seibel MM, Schomer DL, Vaitukaitis JL, Geschwind N (1986b) Reproductive endocrine disorders in men with partial seizures of temporal lobe origin. Arch Neurol 43:347-350. CrossRef

Herzog AG, Drislane FW, Schomer DL, Levesque LA, Ives J, Blume HW, Dubuisson D, Cosgrove GR (1990) Abnormal pulsatile secretion of luteinizing hormone in men with epilepsy: relationship to laterality and nature of paroxysmal discharges. Neurology 40: 1557-1561. Medline

Herzog AG, Klein P, Ransil BJ (1997) Three patterns of catamenial epilepsy. Epilepsia 38:1082-1088. Medline

Herzog AG, Coleman AE, Jacobs AR, Klein P, Friedman MN, Drislane FW, Ransil BJ, Schomer DL (2003) Interictal EEG discharges, reproductive hormones, and menstrual disorders in epilepsy. Ann Neurol 54:625-637. CrossRef Medline

Herzog AG, Harden CL, Liporace J, Pennell P, Schomer DL, Sperling M, Fowler K, Nikolov B, Shuman S, Newman M (2004) Frequency of catamenial seizure exacerbation in women with localization-related epilepsy. Ann Neurol 56:431-434. CrossRef Medline

Herzog AG (2008) Disorders of reproduction in patients with epilepsy: primary neurological mechanisms. Seizure 17:101-110. CrossRef Medline

Hoffman GE, Smith MS, Verbalis JG (1993) c-Fos and related immediate early gene products as markers of activity in neuroendocrine systems. Front Neuroendocrinol 14:173-213. CrossRef Medline

Jasoni CL, Todman MG, Han S-K, Herbison AE (2005) Expression of mRNAs encoding receptors that mediate stress signals in gonadotropin-releasing hormone neurons of the mouse. Neuroendocrinology 82:320-328. CrossRef Medline

Kalinin VV, Zheleznova EV (2007) Chronology and evolution of temporal lobe epilepsy and endocrine reproductive dysfunction in women: relationships to side of focus and catameniality. Epilepsy Behav 11:185-191. CrossRef Medline

Kelly MJ, Wagner EJ (2002) GnRH neurons and episodic bursting activity. Trends Endocrinol Metab 13:409-410. Medline

Klein P, Serje A, Pezzullo JC (2001) Premature ovarian failure in women with epilepsy. Epilepsia 42:1584-1589. Medline

Laidlaw J (1956) Catamenial epilepsy. Lancet 268:1235-1237. CrossRef

Lawrence C, Martin BS, Sun C, Williamson J, Kapur J (2010) Endogenous neurosteroid synthesis modulates seizure frequency. Ann Neurol 67:689-693. CrossRef Medline

Leipheimer RE, Bona-Gallo A, Gallo RV (1984) The influence of progesterone and estradiol on the acute changes in pulsatile luteinizing hormone release induced by ovariectomy on diestrus day 1 in the rat. Endocrinology 114:1605-1612. CrossRef Medline

Li J, Kim JS, Abejuela VA, Lamano JB, Klein NJ, Christian CA (2017) Disrupted female estrous cyclicity in the intrahippocampal kainic acid mouse model of temporal lobe epilepsy. Epilepsia Open 2:39-47. CrossRef Medline

Löfgren E, Mikkonen K, Tolonen U, Pakarinen A, Koivunen R, Myllyla VV, Tapanainen JS, Isojärvi JI (2007) Reproductive endocrine function in women with epilepsy: the role of epilepsy type and medication. Epilepsy Behav 10:77-83. CrossRef Medline

Madisen L, Zwingman TA, Sunkin SM, Oh SW, Zariwala HA, Gu H, Ng LL, Palmiter RD, Hawrylycz MJ, Jones AR (2010) A robust and high-throughput Cre reporting and characterization system for the whole mouse brain. Nat Neurosci 13:133-140. CrossRef Medline

Maguire JL, Stell BM, Rafizadeh M, Mody I (2005) Ovarian cyclelinked changes in GABAA receptors mediating tonic inhibition alter seizure susceptibility and anxiety. Nat Neurosci 8:797-804. CrossRef
Margerison JH, Corsellis JA (1966) Epilepsy and the temporal lobes. A clinical, electroencephalographic and neuropathological study of the brain in epilepsy, with particular reference to the temporal lobes. Brain 89:499-530. Medline

Mattis J, Brill J, Evans S, Lerner TN, Davidson TJ, Hyun M, Ramakrishnan C, Deisseroth K, Huguenard JR (2014) Frequencydependent, cell type-divergent signaling in the hippocamposeptal projection. J Neurosci 34:11769-11780. CrossRef Medline

Meo R, Bilo L, Nappi C, Tommaselli AP, Valentino R, Nocerino C, Striano S, Buscaino GA (1993) Derangement of the hypothalamic $\mathrm{GnRH}$ pulse generator in women with epilepsy. Seizure 2:241-252. Medline

Moenter SM, DeFazio RA, Pitts GR, Nunemaker CS (2003) Mechanisms underlying episodic gonadotropin-releasing hormone secretion. Front Neuroendocrinol 24:79-93. CrossRef

Moenter SM, Chu Z, Christian CA (2009) Neurobiological mechanisms underlying oestradiol negative and positive feedback regulation of gonadotrophin-releasing hormone neurones. J Neuroendocrinol 21:327-333. CrossRef Medline

Norberg R, Campbell R, Suter KJ (2013) lon channels and information processing in GnRH neuron dendrites. Channels 7:135-145. CrossRef Medline

Nunemaker CS, DeFazio RA, Moenter SM (2002) Estradiol-sensitive afferents modulate long-term episodic firing patterns of $\mathrm{GnRH}$ neurons. Endocrinology 143:2284-2292. CrossRef Medline

Paxinos G, Franklin KBJ (2012) The mouse brain in stereotaxic coordinates, Ed 4. London: Elsevier Academic Press.

Pielecka J, Quaynor SD, Moenter SM (2006) Androgens increase gonadotropin-releasing hormone neuron firing activity in females and interfere with progesterone negative feedback. Endocrinology 147:1474-1479. CrossRef Medline

Quigg M, Kiely JM, Shneker B, Veldhuis JD, Bertram EH (2002) Interictal and postictal alterations of pulsatile secretions of luteinizing hormone in temporal lobe epilepsy in men. Ann Neurol 51: 559-566. CrossRef Medline

Raedt R, Van Dycke A, Van Melkebeke D, De Smedt T, Claeys P, Wyckhuys T, Vonck K, Wadman W, Boon P (2009) Seizures in the intrahippocampal kainic acid epilepsy model: characterization using long-term video-EEG monitoring in the rat. Acta Neurol Scand 119:293-303. Medline

Ramcharan EJ, Gnadt JW, Sherman SM (2000) Burst and tonic firing in thalamic cells of unanesthetized, behaving monkeys. Vis Neurosci 17:55-62. Medline

Reddy DS, Rogawski MA (2012) Neurosteroids - Endogenous regulators of seizure susceptibility and role in the treatment of epilepsy. In: Jasper's basic mechanisms of the epilepsies (Noebels JL, Avoli M, Rogawski MA, Olsen RW, Delgado-Escueta AV, eds). Bethesda, MD: National Center for Biotechnology Information (US).

Riban V, Bouilleret V, Pham-Le B, Fritschy JM, Marescaux C, Depaulis A (2002) Evolution of hippocampal epileptic activity during the development of hippocampal sclerosis in a mouse model of temporal lobe epilepsy. Neuroscience 112:101-111. CrossRef

Runtz L, Girard B, Toussenot M, Espallergues J, Fayd'Herbe De Maudave A, Milman A, deBock F, Ghosh C, Guérineau NC, Pascussi JM, Bertaso F, Marchi N (2018) Hepatic and hippocampal cytochrome P450 enzyme overexpression during spontaneous recurrent seizures. Epilepsia 59:123-134. CrossRef

Sarkar DK, Fink G (1980) Luteinizing hormone releasing factor in pituitary stalk plasma from long-term ovariectomized rats: effects of steroids. J Endocrinol 86:511-524. Medline

Scharfman HE, Kim M, Hintz TM, MacLusky NJ (2008) Seizures and reproductive function: insights from female rats with epilepsy. Ann Neurol 64:687-697. CrossRef Medline

Sheybani L, Birot G, Contestabile A, Seeck M, Kiss JZ, Schaller K, Michel CM, Quairiaux C (2018) Electrophysiological evidence for the development of a self-sustained large-scale epileptic network in the kainate mouse model of temporal lobe epilepsy. J Neurosci 38:3776-3791. CrossRef Medline 
Smith MA, Perrin MH, Vale WW (1983) Desensitization of cultured pituitary cells to gonadotropin-releasing hormone: evidence for a post-receptor mechanism. Mol Cell Endocrinol 30:85-96. Medline

Sullivan SD, Moenter SM (2005) GABAergic integration of progesterone and androgen feedback to gonadotropin-releasing hormone neurons. Biol Reprod 72:33-41. CrossRef Medline

Talbot JA, Sheldrick R, Caswell H, Duncan S (2008) Sexual function in men with epilepsy How important is testosterone? Neurology 70:1346-1352. CrossRef Medline

Terasawa E, Kawakami M (1973) Effects of limbic forebrain ablation on pituitary gonadal function in the female rat. Endocrinol Jpn 20:277-289. Medline

Todman MG, Han SK, Herbison AE (2005) Profiling neurotransmitter receptor expression in mouse gonadotropin-releasing hormone neurons using green fluorescent protein-promoter transgenics and microarrays. Neuroscience 132:703-712. CrossRef Medline

Velasco ME, Taleisnik S (1969) Effect of hippocampal stimulation on the release of gonadotropin. Endocrinology 85:1154-1159. CrossRef Medline

Wakerley JB, Lincoln DW (1973) The milk-ejection reflex of the rat: a 20 - to 40 -fold acceleration in the firing of paraventricular neurones during oxytocin release. J Endocrinol 57:477-493. Medline
Wildt L, Häusler A, Marshall G, Hutchison JS, Plant TM, Belchetz PE, Knobil E (1981) Frequency and amplitude of gonadotropinreleasing hormone stimulation and gonadotropin secretion in the rhesus monkey. Endocrinology 109:376-385. CrossRef Medline

Wintermantel TM, Campbell RE, Porteous R, Bock D, Gröne HJ, Todman MG, Korach KS, Greiner E, Pérez CA, Schütz G, Herbison AE (2006) Definition of estrogen receptor pathway critical for estrogen positive feedback to gonadotropin-releasing hormone neurons and fertility. Neuron 52:271-280. CrossRef Medline

Xu C, Xu XZ, Nunemaker CS, Moenter SM (2004) Dose-dependent switch in response of gonadotropin-releasing hormone $(\mathrm{GnRH})$ neurons to $\mathrm{GnRH}$ mediated through the type I $\mathrm{GnRH}$ receptor. Endocrinology 145:728-735. CrossRef Medline

Yoon H, Enquist L, Dulac C (2005) Olfactory inputs to hypothalamic neurons controlling reproduction and fertility. Cell 123:669-682. CrossRef Medline

Zhou JQ, Zhou LM, Chen LJ, Han JD, Wang Q, Fang ZY, Chen ZY, Ling $S$ (2012) Polycystic ovary syndrome in patients with epilepsy: a study in 102 Chinese women. Seizure 21:729-733. CrossRef Medline 